\title{
Changes in Human Mucosal $\gamma \delta$ T Cell Repertoire and Function Associated with the Disease Process in Inflammatory Bowel Disease
}

\author{
Laila D. McVay,* Baiqing Li,* Renée Biancaniello,* \\ Mary Anne Creighton,* Dale Bachwich, ${ }^{\neq}$Gary Lichtenstein, ${ }^{\neq}$ \\ John L. Rombeau, $\$$ and Simon R. Carding* \\ *Department of Microbiology, ${ }^{\ddagger}$ Division of Gastroenterology, and \\ ${ }^{\S}$ Department of Surgery, University of Pennsylvania School of \\ Medicine, Philadelphia, Pennsylvania 19104-6021, U.S.A.
}

\begin{abstract}
Background: Although $\gamma \delta \mathrm{T}$ cells are a major component of the human intestinal mucosa, it is not clear what role they play in mucosal immunity or if they are involved in the disease process of inflammatory bowel disease (IBD).

Materials and Methods: Flow cytometry and reverse transcriptase-polymerase chain reaction (RT-PCR) assays were used to identify quantitative and qualitative changes in the repertoire of $\gamma \delta \mathrm{T}$ cells present in surgical and/or biopsy samples of normal and inflamed colon from individual patients with ulcerative colitis (UC) or Crohn's disease (CD). Cytokine production and the ability to adhere to and interact with colonic fibroblasts were used to compare the functional properties of $\gamma \delta \mathrm{T}$ cells isolated from the normal and diseased colonic mucosa. Results: Increased numbers of $\gamma \delta \mathrm{T}$ cells localized in areas of inflammation and tissue injury were found in
\end{abstract}

the majority of patients, irrespective of the type of IBD present. This expansion was attributable to an increase in $\mathrm{V} \delta 1^{+}$cells expressing a $\mathrm{V} \delta 1-(\mathrm{D} \delta 3)-\mathrm{J} \delta 1$-encoded $\mathrm{T}$ cell receptor and was seen in patients with severe disease as well as those with newly diagnosed or less severe forms of IBD. Among T cells present in the inflamed mucosa of patients with $\mathrm{CD}, \gamma \delta \mathrm{T}$ cells, particularly $\mathrm{V} \delta \mathrm{1}^{+}$cells, were a major source of the proinflammatory cytokine interferon- $\gamma$ and could interact with colonic fibroblasts.

Conclusions: Our results demonstrate that the chronic inflammatory immune response characteristic of IBD is associated with distinct changes in the number, distribution, composition, and function of mucosal $\gamma \delta \mathrm{T}$ cells. Through the production of cytokines and physical interaction with other cells, $\gamma \delta$ T cells can perform an immunoregulatory function and contribute to the pathophysiology of IBDs.

\section{INTRODUCTION}

Inflammatory bowel disease (IBD) represents a complex group of idiopathic chronic inflammatory disorders of which Crohn's disease (CD) and ulcerative colitis (UC) are the major forms. While there are several features that distinguish $\mathrm{CD}$ and

Address correspondence and reprint requests to: Simon $\mathrm{R}$. Carding, Department of Microbiology, 802F Abramson Center, 34th Street 8 Civic Center Blvd., Philadelphia, PA 19104, U.S.A. Phone: 215-573-3022; Fax: 215-573-9068; E-mail: carding@mail.med.upenn.edu
UC, there are many epidemiological, clinical, radiologic, endoscopic, and histologic features that are shared between these two disorders.

Several immunologic and histopathologic features of UC and CD can be explained as a defect in mucosal immunoregulation, and as a direct or indirect consequence of persistent mucosal $\mathrm{T}$ cell activation (1-4). Experimental evidence for a direct role for T cells in IBD comes from various animal models, especially "gene knock-out" strains that spontaneously develop bowel lesions. In particular, the presence of intestinal inflammation in transgenic mice deficient in $\alpha \beta$ T cells (5) or T cell-derived cytokines 
such as interleukin 2 (IL-2) (6) suggest that T cells are responsible for the homeostatic regulation of mucosal immune responses.

In the human intestine, $\gamma \delta^{+}$cells are a major component $(30-40 \%)$ of the $\mathrm{T}$ cells in the intraepithelial spaces and the majority $(>70 \%)$ express $V \delta 1$-encoded receptors (7). In view of the predominance of ${\mathrm{V} \delta 1^{+}}^{+}$cells within the human intestinal mucosa and the possibility that they have similar effector functions to their murine counterparts, it seems likely that they may play an important role in the generation and/or regulation of inflammatory responses in the intestinal mucosa. The ability of $\gamma \delta \mathrm{T}$ cells to interact with and influence the activity of a variety of stromal cells $(8-10)$, including epithelial cells $(8,11)$, and the finding that the severity of IBD in $\mathrm{T}$ cell receptor (TCR)- $\boldsymbol{\alpha} \beta$-deficient mice is significantly reduced when crossed with mice lacking $\gamma \delta \mathrm{T}$ cells (5) are all consistent with an immunoregulatory role for mucosal $\gamma \delta \mathrm{T}$ cells.

Whereas several groups of investigators have described an increase in the number of $\mathrm{V} \delta 1^{+}$ intraepithelial (IE) $\gamma \delta \mathrm{T}$ cells within the intestine of patients with coeliac disease (12-16), the immunohistochemical analyses of mucosal $\gamma \delta \mathrm{T}$ cells in patients with IBD have generated contradictory results $(16,17)$. Although one group has shown that the distribution and relative number of TCR- $\delta^{+}$cells in sections of colonic mucosa obtained from IBD patients was similar to that in sections of normal colonic mucosa (16), the results of another study showed that there were fewer TCR- $\delta^{+}$cells in the inflamed mucosa of patients with IBD, and particularly, those with UC (17). Thus, evidence for the involvement of $\gamma \delta \mathrm{T}$ cells in IBD remains inconclusive. To investigate further the possible involvement of mucosal $\gamma \delta \mathrm{T}$ cells in IBD we have used a combination of sensitive cellular and molecular techniques to determine if there are any qualitative or quantitative changes in $\gamma \delta$ populations in the colonic mucosa of patients with CD and UC.

The results of our studies identify changes in the number, distribution, and repertoire of $\gamma \delta \mathrm{T}$ cells that are present within the lesions of the inflamed intestine in both UC and CD. The finding that, in contrast to $\gamma \delta \mathrm{T}$ cells present in the healthy, noninvolved mucosa, $\gamma \delta$ cells in the inflamed mucosa constitutively produce the inflammatory cytokine interferon $\gamma$ (IFN- $\gamma$ ) and selectively interact with colonic stromal (fibroblasts) cells suggest that mucosal $\gamma \delta \mathrm{T}$ cells can contribute to the development of the disease process in IBD.

\section{MATERIALS AND METHODS}

\section{Procurement and Processing of Patient Samples}

Surgical resectioned segments of intact colon were obtained from patients with UC, CD, or diverticular disease (diverticulitis) at the time of elective surgery. Histologically normal, noninvolved, mucosa was obtained from the margins of surgical resectioned colon that were at least a distance of $15 \mathrm{~cm}$ from any lesions. Mucosal biopsies were obtained with the approval of the Human Investigations Committee of the University of Pennsylvania School of Medicine. The origin and nature of the patient samples used in this study are compiled in Tables 1 and 2 . When available, peripheral blood mononuclear cells (PBMCs) from the same patient were used as control samples. Patient-derived samples were used for RNA extraction, reverse transcriptasepolymerase chain reaction (RT-PCR) analysis, in situ hybridization, and/or cell isolation for flow cytometric and functional analyses.

\section{Cell Isolation}

Peripheral blood mononuclear cells were isolated from 5 to $10 \mathrm{ml}$ of peripheral blood by density gradient centrifugation using Ficoll-Hypaque (Organo-Teknika, Durham, NC) and washed one to two times with PBS. Established human fibroblast cell lines of skin (CRL-1509), lung (CCD$11 \mathrm{Lu})$, or colon (CCD-18Co) origin were obtained from the American Type Culture Collection (ATCC, Rockville, MD). A primary colonic fibroblast cell line was derived from the involved mucosal tissue fragments of a patient with ileocolonic CD (CD-11, Table 1) as described previously (18). This line was maintained in Dulbecco's modified Eagle's medium (DMEM) containing $10 \%$ fetal calf serum (FCS) and penicillin/streptomycin/bactrim/amphotericin B. Prior to reaching confluency, cells were trypsinized and diluted 1:5 in complete media and plated into tissue culture-treated $20-\mathrm{mm}$ petri dishes. Adherence assays were performed with primary fibroblasts that had been passaged twice.

\section{IE and Lamina Propria (LP) T Cells}

A modified version of a previously published procedure (19) was used to isolate IE and LP lymphocytes (L). Briefly, after removal of all associated mesentery, fat, and underlying muscularis, the mucosa was washed to remove mucus 
and cut into 2 - to $3-\mathrm{cm}$ pieces. IE lymphocytes were eluted by 3 to 4 sequential incubations with Hank's balanced salt solution (HBSS) containing $0.1 \mathrm{mM}$ EDTA at $37^{\circ} \mathrm{C}$ each for $15 \mathrm{~min}$ with constant magnetic stirring. The eluted cells were then subjected to two-step discontinuous Percoll (Pharmacia-LKB, Uppsala, Sweden) gradient centrifugation at $600 \times g$ for 20 min using $70 \%$ and $40 \%$ Percoll. IEL were removed from the interface between the $70 \%$ and $40 \%$ Percoll layers. The remaining tissue fragments were incubated with HBSS containing collagenase type IV (Sigma, St. Louis, MO) at $37^{\circ} \mathrm{C}$ for $4-6 \mathrm{hr}$ with constant stirring. The recovered LP cell suspension was then subjected to Ficoll-Hypaque density gradient centrifugation to isolate viable cells from which LP lymphocytes were obtained by Percoll gradient centrifugation as described above for IEL isolation. The yield of LP T cells $\left(\mathrm{CD}^{+}\right.$cells) from the noninvolved mucosa and from the involved mucosa was calculated as the number of cells per gram of tissue used for isolation, and this yield was routinely comparable to that reported by others $(20,21)$.

IMMUNOMAGNETIC SELECTION OF MUCOSAL IEL AND LP $\gamma \delta^{+} T$ CELLS. A negative-immunomagnetic selection procedure (22) was used to obtain homogenous populations of TCR- $\gamma \delta^{+}$or TCR- $\alpha \beta^{+}$IEL and LP cells from the involved and noninvolved mucosa of colonic surgical specimens. Briefly, total LP and IEL cell samples were sequentially incubated with a mouse anti-human TCR- $\alpha \beta$ (clone BW242/412; T Cell Diagnostics, Woburn, MA) or a mouse anti-human TCR- $\gamma \delta$ antibody (11F2, Becton Dickinson) and a rabbit antimouse immunoglobulin G (IgG) antibody conjugated to supramagnetic particles (BioMag Beads, Perseptive Diagnostics, Cambridge, MA). The cells were then transferred to a $25-\mathrm{cm}^{2}$ tissue culture flask and placed on a plate magnet and the "nonmagnetized" cells were removed. The purity of each $\mathrm{T}$ cell population was determined by flow cytometry, and cell viability, by trypan blue dye exclusion.

\section{Flow Cytometry}

Aliquots $\left(0.2-1.0 \times 10^{6}\right)$ of bulk or fractionated IEL and LP mononuclear cells were stained with fluorochrome-conjugated mouse anti-human CD3- (clone S4.1; Caltag Labs., San Francisco, CA), CD $8 \alpha-(3 B 5$, Caltag), TCR- $\gamma \delta-(11 F 2$, Becton Dickinson), TCR-V $\gamma 9-$ (T Cell Diagnostics), TCR-V $\delta 1$ - (TS8.2; T Cell Diagnostics), TCR-V $\delta 1$ -
J $\delta 1-(\delta \mathrm{TCS}-1$; T Cell Diagnostics) and/or TCRVס2- (23) specific antibodies, fixed and analyzed on a FACScan (Becton Dickinson) using Lysis II or CellQuest software as described previously (23). Fluorochrome-conjugated isotype-matched mouse antibodies or irrelevant specificity (Caltag) and anti-human CD45-specific antibodies (Dako Corporation, Carpinteria, CA) were used to control for nonspecific reactivity and as fluorochrome-compensation controls, respectively.

\section{RT-PCR Analysis of the TCR-V $\delta$ Repertoire}

Total cellular RNA was prepared from intestinal tissue or PBMC by CsCl density gradient centrifugation (24). RNA pellets were extracted with acidic phenol once, with phenol:chloroform ( $1: 1)$ once, and twice with chloroform prior to ethanol precipitation. Approximately $10 \mu \mathrm{g}$ of total cellular RNA was used to synthesize cDNA using random hexanucleotides as described previously (25). A nested PCR assay (24) was used to analyze the $\mathrm{V} \delta$-J $\delta$ rearrangements expressed by $\gamma \delta \mathrm{T}$ cells in colonic tissue and blood mononuclear cell RNA/cDNA samples. Briefly, oligonucleotide primers specific for $\mathrm{V} \delta 1, \mathrm{~V} \delta 2$, or $\mathrm{V} \delta 3$ in combination with a $C \delta$ gene segment primer were used to amplify cDNA. The products of amplification were electrophoresed and TCRPCR products gel purified and quantitated by DNA fluorimetry. Equivalent amounts of each cDNA were used as a template for a second amplification using the same forward $V \delta$ primer and a reverse-primer specific for each of the four human $\mathrm{J} \delta$ genes. The products of amplification were electrophoresed on $1.8 \%$ agarose gels, Southern blotted, and hybridized with $\left[\gamma^{32} \mathrm{P}\right]-$ ATP end-labeled V $\delta 1, V \delta 2$, or V $\delta 3$ oligonucleotide probes containing sequence internal to the $\mathrm{V} \delta$ primers used for PCR. Individual V $\delta 1-\mathrm{J} \delta 1-4$, $\mathrm{V} \delta 2-\mathrm{J} \delta 1-4$, and $\mathrm{V} \delta 3-\mathrm{J} \delta 1-4$ receptor cDNA clones were used to determine the optimum conditions for the proportional amplification of $\mathrm{V} \delta$-J $\delta$ genes with no cross-priming. For analysis of mucosal biopsy specimens, 5 to 6 individual pieces of tissue were pooled and total cellular RNA was isolated as described above. After generating CDNA, aliquots were analyzed for $\mathrm{V} \delta 1-\mathrm{J} \delta$ expression by PCR amplification and Southern blot analysis as described for the surgical samples. 


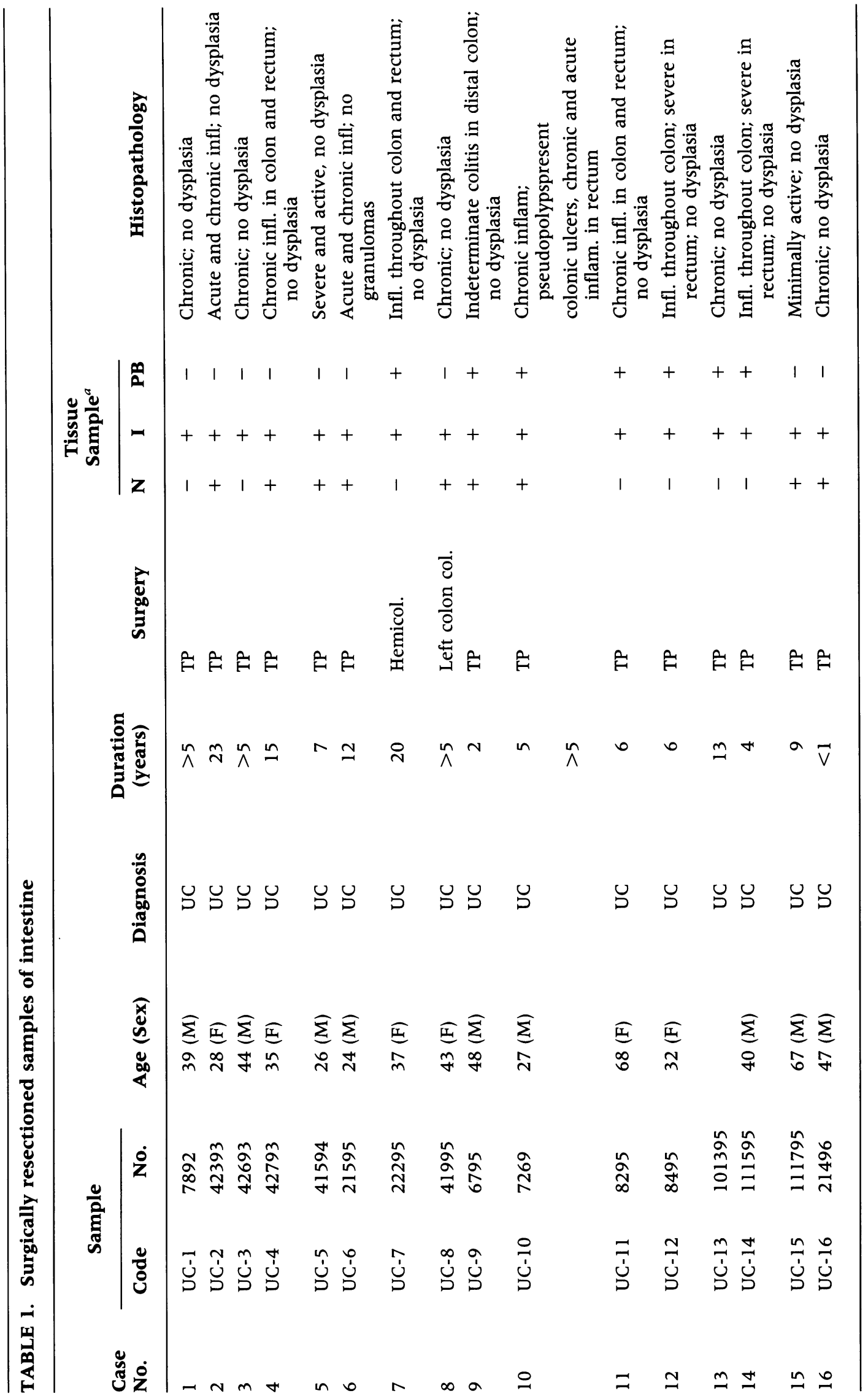




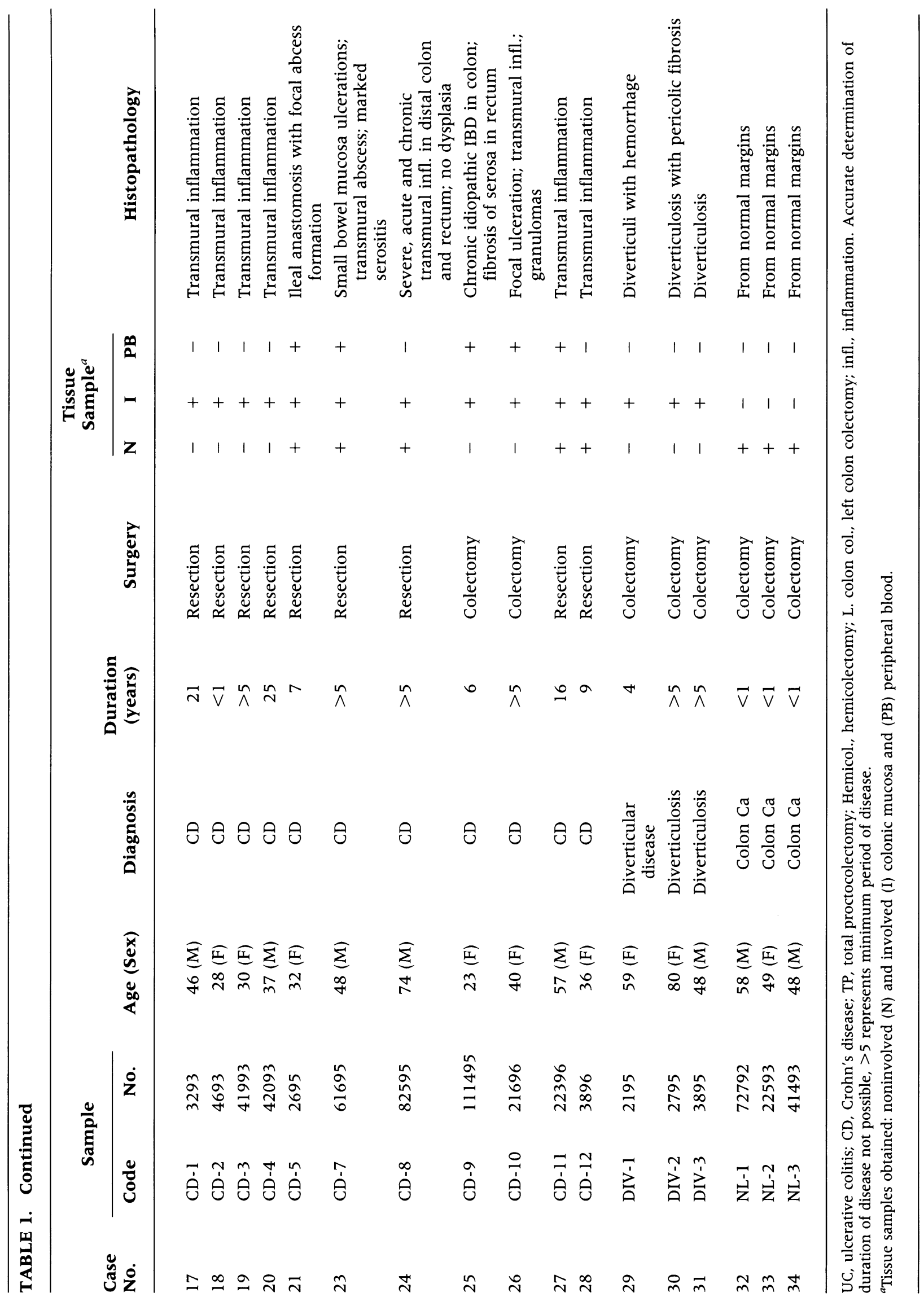


TABLE 2. Biopsy samples of intestinal tissue

\begin{tabular}{|c|c|c|c|c|c|c|c|c|}
\hline \multirow{2}{*}{$\begin{array}{l}\text { Case } \\
\text { No. }\end{array}$} & \multicolumn{2}{|c|}{ Sample } & \multirow[b]{2}{*}{ Age (Sex) } & \multirow[b]{2}{*}{ Diagnosis } & \multirow{2}{*}{$\begin{array}{c}\text { Duration } \\
\text { (years) }\end{array}$} & \multicolumn{3}{|c|}{ Tissue Sample } \\
\hline & Code & No. & & & & $\mathbf{N}$ & I & PB \\
\hline 1 & Bl-UC & 82494 & $26(M)$ & UC & 15, recurrence & + & + & - \\
\hline 2 & B2-UC & 21495 & $25(M)$ & Pan UC & 12 , recurrence & + & + & - \\
\hline 3 & B3-UC & 11295 & $37(\mathrm{M})$ & Nonspecific colitis & 1 week & + & + & + \\
\hline 4 & B4-UC & 72194 & $(\mathrm{M})$ & UC & 5, recurrence & - & + & - \\
\hline 5 & B5-UC & 12795 & $47(\mathrm{~F})$ & Active UC & $5-6$, recurrence & - & + & - \\
\hline 6 & B6-UC & 9894 & $66(M)$ & Noninvolved UC & 13 , recurrence & + & - & - \\
\hline 7 & B7-UC & 3895 & $28(\mathrm{M})$ & UC & 5 , recurrence & - & + & + \\
\hline 8 & B8-CD & 72794 & $(\mathrm{~F})$ & $\mathrm{CD}$ & 2 , recurrence & - & + & - \\
\hline
\end{tabular}

N, noninvolved; I, involved; $\mathrm{PB}$, peripheral blood; UC, ulcerative colitis; $\mathrm{CD}$, Crohn's disease.

\section{In Situ Hybridization}

In situ hybridization was used to identify and localize populations of $\gamma \delta \mathrm{T}$ cells and IFN- $\gamma$-producing cells within frozen sections of intestine as described previously $(22,26,27)$. Briefly, 1 - to $2-\mathrm{cm}^{2}$ pieces of tissue from involved or noninvolved areas along the length of the resected intestine were snap frozen in Tissue Tek (Miles, Elkhard, IN) and stored at $-86^{\circ} \mathrm{C}$. Six- $10 \mu \mathrm{m}$ sections were cut from tissue blocks using a cryostat, fixed in $4 \%$ paraformaldehyde in PBS, $\mathrm{pH}$ 7.4, for $20 \mathrm{~min}$ at room temperature, then stored in $70 \%$ ethanol at $4^{\circ} \mathrm{C}$ in airtight containers. ${ }^{35} \mathrm{~S}$-labeled RNA probes $(0.2 \mathrm{ng}$ RNA/ $\mu \mathrm{l}$; specific activity $>10^{9} \mathrm{cpm} / \mu \mathrm{g}$ ) complimentary to the coding (antisense) or noncoding (sense) sequences human IFN- $\gamma(26)$ genes were used for detection of TCR- and IFN- $\gamma$-mRNA ${ }^{+}$cells.

\section{IFN- $\boldsymbol{\gamma}$ Assay}

IFN- $\gamma$ protein production was analyzed from bulk, nonfractionated $\mathrm{T}$ cells and purified $\alpha \beta \mathrm{T}$ cells, and $\gamma \delta \mathrm{T}$ cells isolated from segments of noninvolved or involved mucosa from two patients with ileocolonic $\mathrm{CD}$ and one with colonic CD. Two hundred thousand cells were cultured in triplicate in microtiter plate wells containing either media alone or wells coated with an antiCD3 antibody (OKT3). After $96 \mathrm{hr}$, the culture supernatant was harvested and assayed for IFN- $\gamma$ using a commercial radioimmunoassay (RIA) kit (Centocor, Malvern, PA). The amount of IFN- $\gamma$ present was determined by reference to a stan- dard curve generated from samples containing known amounts of rIFN- $\gamma$ assayed in parallel.

\section{Fibroblast Adherence Assay}

T cells $\left(3 \times 10^{6}\right)$ from peripheral blood and/or normal or involved colon from four patients with ileocolonic $\mathrm{CD}$ were allowed to adhere to confluent monolayers of established or primary fibroblast cell lines in $20-\mathrm{mm}$ petri dishes at $37^{\circ} \mathrm{C}$ for $30 \mathrm{~min}$. Nonadherent cells were removed by gentle washing with prewarmed media and adherent cells removed by brief (3-5 min) trypsin treatment. The number of adherent cells was determined and the $\mathrm{T}$ cell composition evaluated by flow cytometry. The degree of enrichment for $\gamma \delta \mathrm{T}$ cells after adherence to fibroblast monolayers was determined by the number of $\gamma \delta \mathrm{T}$ cells present in the input and adherent cells. The proportion of mucosal $\mathrm{V} \delta 1^{+} \gamma \delta$ T cells able to adhere to fibroblasts was determined from the number of $\mathrm{V} \delta \mathrm{l}^{+}$cells present in the input and adherent cell populations.

\section{RESULTS}

In situ hybridization was used initially to visualize and localize TCR- $\gamma \delta^{+}$cells in frozen sections of normal and diseased colonic mucosa. Compared with sections of normal colonic mucosa, sections of diseased tissue (CD) contained many more TCR- $\delta$-mRNA ${ }^{+}$cells that were distributed throughout the mucosa and submucosa and within the vasculature and connective tissue of 
the muscularis mucosa and serosa (data not shown). This distribution was consistent with the transmural pathology of $\mathrm{CD}$. In order to analyze the distribution of $\gamma \delta \mathrm{T}$ cells in the normal and inflamed colon in more detail, flow cytometry was used to analyze cells directly after their isolation from the colonic mucosa.

\section{Changes in the Number, Distribution, and Composition of Isolated Mucosal TCR- $\gamma \delta^{+}$ $T$ Cells in Noninvolved and Involved Tissue from the Same Patient}

Three-color flow cytometry was used to compare the number, distribution, and composition of $\gamma \delta$ $T$ cells in the IE space and LP of the noninvolved and involved mucosa of individual IBD patients. This approach was preferred to immunohistochemical detection of $\mathrm{T}$ cells in intestinal tissue since this technique is more tedious and labor intensive, it is difficult to perform, and it is a relatively insensitive means of detecting antigens such as the $\gamma \delta$ TCR that are expressed at low levels $(28,29)$. For our study, surgically resectioned segments of colon from a total of seven patients with colonic CD or UC were used for this study. It should be noted that in contrast to the small bowel which is rich in IELs, the colon has relatively few IELs. Peripheral blood samples from these patients were analyzed in parallel.

The cytofluorographs of the analysis of one UC patient sample (Fig. IA) and the compiled analysis of all seven IBD patients (Fig. 1B) identify differences in the distribution, number, and composition of $\gamma \delta \mathrm{T}$ cells in the blood and intestine. In the blood, $\gamma \delta \mathrm{T}$ cells comprised a small proportion of $\mathrm{T}$ cells $(3-4 \%)$, of which $>95 \%$ were $\mathrm{CD}^{-}, \mathrm{CD}^{-}$(data not shown) and expressed a TCR encoded by the $\mathrm{V} \gamma 9$ and $\mathrm{V} \delta 2$ gene segments (Fig. 1B). By contrast, in the colon, $\gamma \delta$ $\mathrm{T}$ cells made up a larger proportion of the $\mathrm{T}$ cells present in the colonic mucosa, particularly in the IE space $(20-30 \%)$. Less than $10 \%$ of the IEL population were $\mathrm{CD} 19^{+}$, demonstrating that the IEL preparations contained low levels of contaminating LP lymphocytes. The $10-20 \%$ of $\mathrm{CD}^{-}$ cells present in the IEL preparations were $\mathrm{CD} 45^{-}$ (data not shown), which is consistent with them being contaminating epithelial cells.

In the involved mucosa of all of the IBD samples analyzed, $\gamma \delta \mathrm{T}$ cells comprised a major $\mathrm{T}$ cell population in the LP of CD (mean, 43\%; range, 23-63\%) and UC (mean, 64\%; range, $45-83 \%$ ) patients. Assuming that the mucosal T cell isolation procedure did not result in the selective loss of $\gamma \delta$ T cells (see Materials and Methods), it was possible to determine the relative number of $\gamma \delta \mathrm{T}$ cells present in the involved and noninvolved mucosa. The average yield of $\mathrm{T}$ cells $\left(\mathrm{CD}^{+}{ }^{+}\right)$recovered from the LP was $5.9 \pm 0.4 \times$ $10^{6}$ cells/g from the noninvolved colonic mucosa and $2.4 \pm 0.6 \times 10^{7}$ cells/g from the involved mucosa, which is comparable to the values reported previously $(20,21)$. The proportion of TCR- $\alpha \beta^{+}$and TCR- $\gamma \delta^{+}$cells in the noninvolved mucosa was $74 \% \pm 10 \%$ and $26 \% \pm 9 \%$, respectively (data not shown). Thus, noninvolved colonic mucosa samples contained an average of $1.6 \pm 0.3 \times 10^{6} \gamma \delta \mathrm{T}$ cells/g tissue. Since in the involved mucosa TCR- $\alpha \beta$ and TCR- $\gamma \delta$ represented $54 \% \pm 15 \%$ and $46 \% \pm 22 \%$, respectively, this tissue contained on average $6.9 \pm$ $0.3 \times 10^{6} \gamma \delta$ cells/g tissue, representing an almost 5 -fold increase over that found in the normal mucosa.

Further characterization of the mucosal $\gamma \delta \mathrm{T}$ cells in the normal and inflamed colon using TCR-V $\gamma / \delta$ - $(\mathrm{J} \delta)$-specific antibodies revealed some interesting differences in the $\gamma \delta \mathrm{T}$ cell subsets present (Fig. 1B). In the noninvolved colonic mucosa, ${\mathrm{V} \delta 1^{+}}^{+} \delta \mathrm{T}$ cells comprised a major subset $(43-52 \%)$ of IE $\gamma \delta$ T cells. Of these cells, $\mathrm{V} \delta 1-\mathrm{J} \delta 1$-encoded TCR- $\delta$ chains predominated $\left(63-76 \%\right.$ of $\mathrm{V} \delta 1^{+}$cells). By contrast, in the LP, $\mathrm{V} \delta \mathrm{I}^{+} \gamma \delta \mathrm{T}$ cells represented a minor subset $(6-$ $10 \%)$ of $\gamma \delta \mathrm{T}$ cells; as seen among IEL, $\mathrm{V} \delta 1^{+}-\mathrm{J} \delta 1$ was the predominant $(43-58 \%)$ TCR- $\delta$ chain expressed by these cells. Thus, V $\delta 1-J \delta 1$-encoded receptors predominate among $\mathrm{V} \delta \mathrm{I}^{+} \gamma \delta \mathrm{T}$ cells in both the IE space and LP of the normal colonic mucosa. $\mathrm{V} \gamma 9 / \mathrm{V} \delta 2^{+} \gamma \delta \mathrm{T}$ cells that make up the largest $\gamma \delta \mathrm{T}$ cell subset in the blood (Fig. 1B) had a distribution in the normal colonic mucosa that was reciprocal to that of the $\mathrm{V} \delta \mathrm{l}$ subset. Whereas they represented a minor subset $(13 \%)$ of TCR$\gamma \delta^{+}$IEL, they were the major $\gamma \delta \mathrm{T}$ cell subset in the LP $\left(67-79 \%\right.$ of TCR- $\gamma \delta^{+}$cells).

In comparing the $\gamma \delta \mathrm{T}$ cell subset distribution in the involved and noninvolved mucosa, the most striking difference was the increase in the proportion of $V \delta 1^{+} \gamma \delta$ cells in the LP of the involved mucosa. In both the UC and CD patient groups, ${\mathrm{V} \delta 1^{+}}^{+}$cells represented the major (57$76 \%)$ population of $\gamma \delta \mathrm{T}$ cells, of which most (76-81\%) expressed a V $\delta 1-J \delta 1$-encoded TCR. By contrast, there was no significant difference in the proportion of $\mathrm{V} \delta \mathrm{l}$-bearing $\gamma \delta \mathrm{T}$ cells in the IE space of the involved versus noninvolved mucosa. The inflammatory reaction that occurs in 
A
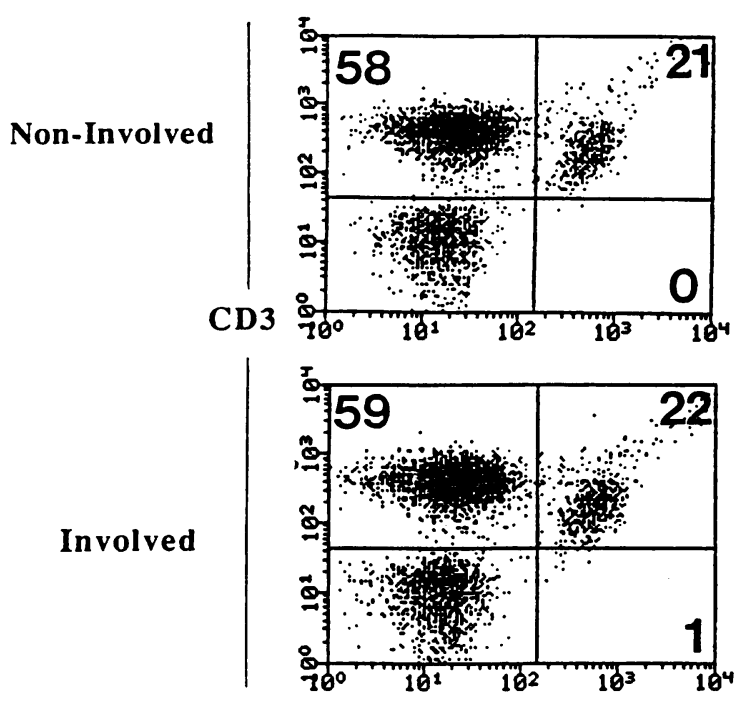

IEL
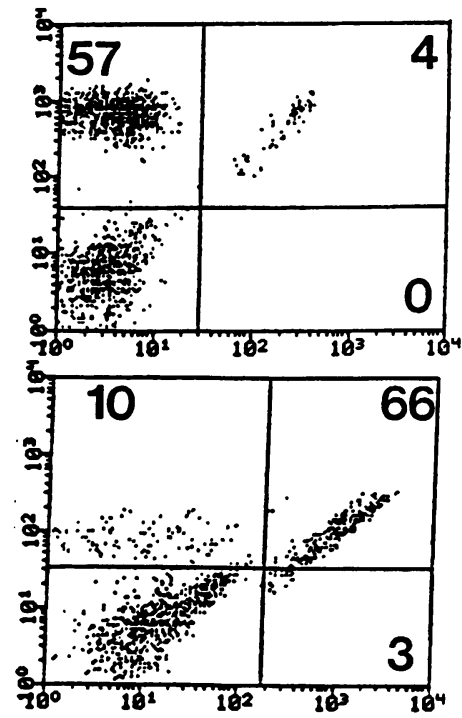

$\gamma \delta$

B

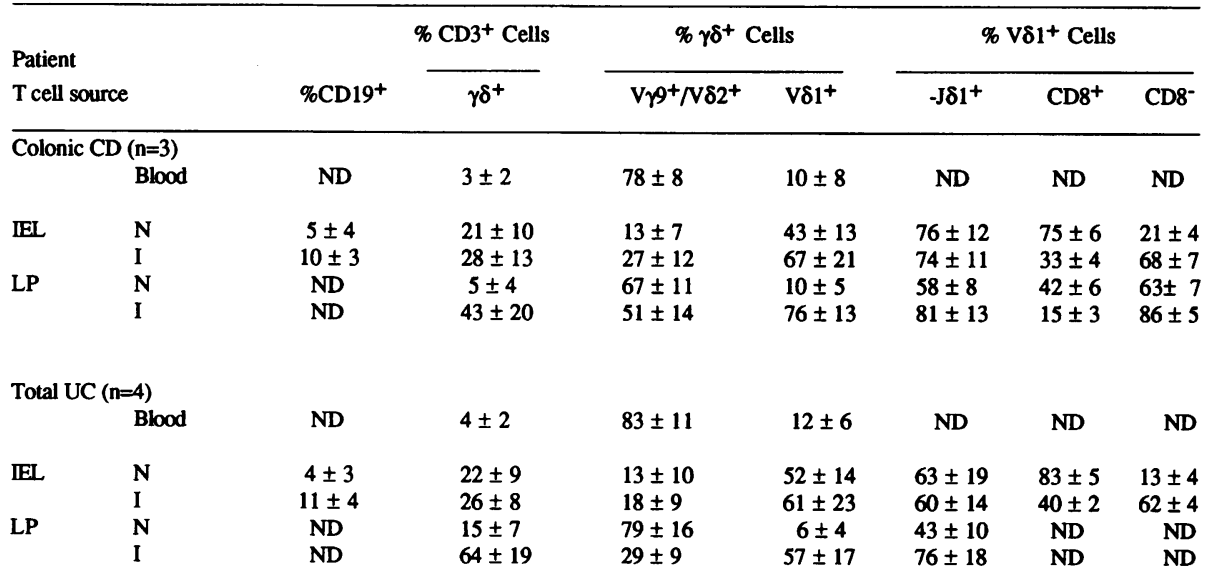

IEL. intraepithelial lymphocytes; LP. lamina propria; N. non-involved colonic mucosa; I. involved colonic mucosa; ND, not determined.

FIG. 1. Distribution of $\boldsymbol{\gamma} \delta \mathrm{T}$ cells in the normal and inflamed intestinal mucosa

(A) Representative analysis of $\gamma \delta \mathrm{T}$ cells present within the intraepithelial space (IEL) and lamina propria (LP) of the colonic mucosa from a patient with total colitis. (B) CD8 expression and TCR-V $\gamma / \delta$ usage by IE- and LP- $\gamma \delta \mathrm{T}$ cells in the blood, noninvolved (N) and involved (I) intestinal mucosa of patients with colonic CD and total colitis. ND, not determined.

the intestinal mucosa of IBD patients is characterized, therefore, by changes in the distribution of $\gamma \delta \mathrm{T}$ cell populations and by the accumulation of $\mathrm{V} \delta 1^{+}$cells in the LP. Although we do not know if this increase in $\gamma \delta \mathrm{T}$ cells and $\mathrm{V} \delta 1^{+}$cells represents expansion of resident mucosal cells or cells infiltrating from the blood, differences in the phenotype of ${\mathrm{V} \delta 1^{+}}^{+}$cells in the LP (and IE spaces) of normal colonic mucosa (majority $\mathrm{CD}^{+}$) versus involved mucosa (majority $\mathrm{CD} 8^{-}$) suggests they are mainly of peripheral origin.

\section{Bias in Expression of $\mathrm{V} \delta 1$-encoded Receptors by $\gamma \delta \mathrm{T}$ Cells in Surgical Resected Tissue Specimens of IBD Patients as Demonstrated by RT-PCR Analysis}

Repertoire analysis using antibodies and flow cytometry is limited by the size of mucosal tissue samples, the number of cells that can be recovered from each sample, and by the availability of TCR-V(J)-specific antibodies. Also, since the 


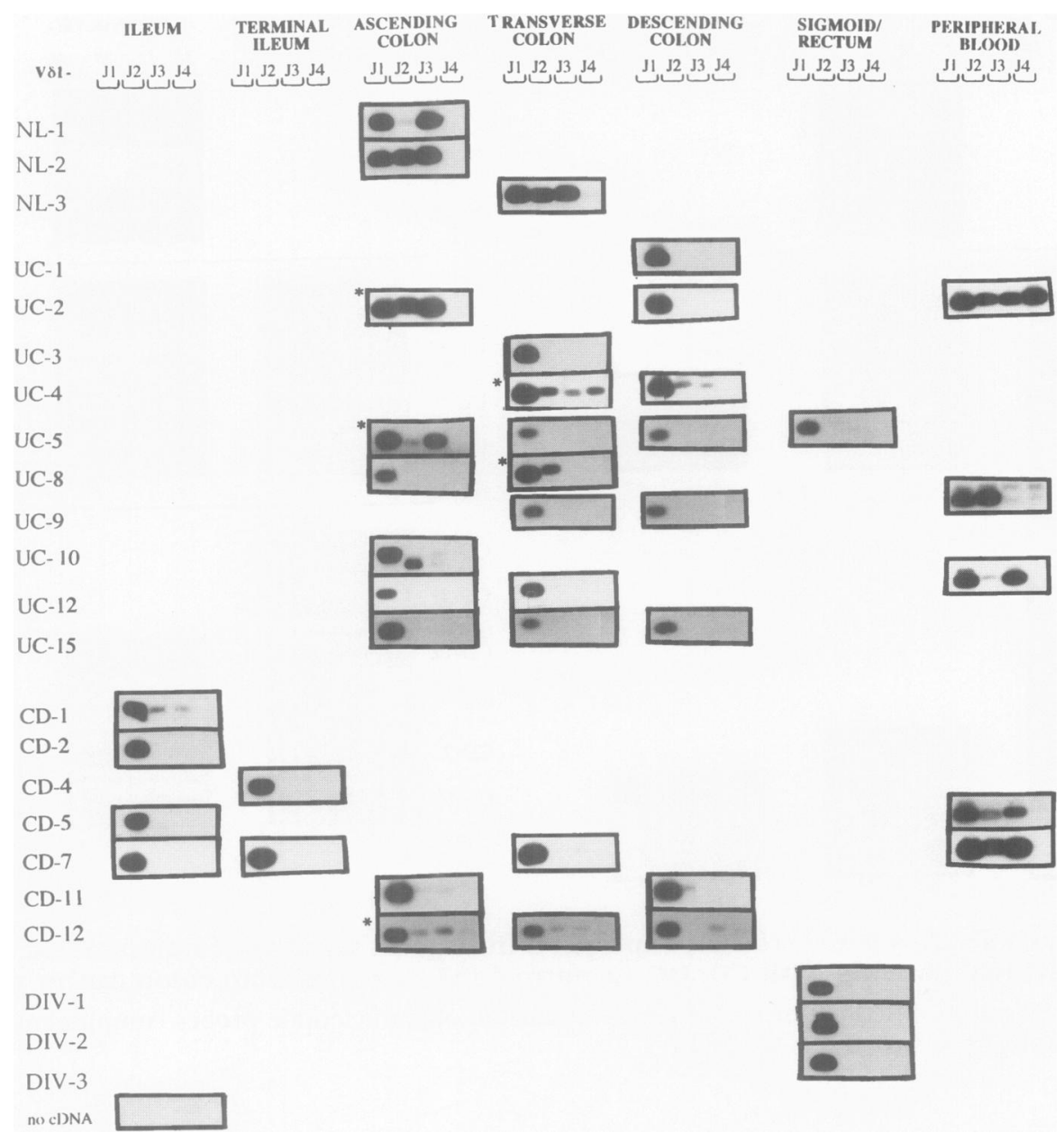

FIG. 2. RT-PCR analysis of V $\mathbf{V} 1-\mathrm{J} \delta$ TCR expression in surgical samples of normal, noninvolved, and inflamed, involved intestine of individual patients with CD, UC, diverticulitis (DIV), or normal (NL) mucosa from various locations along the length of the intestine

Mucosal cDNA samples were amplified first with primers specific for $\mathrm{V} \delta 1$ and $\mathrm{C} \delta$ and the amplified products were gel purified then reamplified in a second PCR reaction with the same V $\delta 1$ primer used for the first amplification and with a reverse primer specific for each of the four $\mathrm{J} \delta$ genes. V $\delta 1-J \delta$ PCR products were electrophoresed through $2 \%$ agarose gels, blotted, and probed with an internal ${ }^{32} \mathrm{P}$-labeled $\mathrm{V} \delta 1$-specific oligonucleotide probe. Autoradiography was carried out for $24 \mathrm{hr}$. Asterisks indicate V $\delta$-J $\delta$ profile of noninvolved colonic mucosa.

$\mathrm{V} \delta 1-\mathrm{J} \delta 1$-specific antibody may have some reactivity with $\mathrm{J} \delta$-encoded receptors other than $\mathrm{J} \delta 1$ (30), it was important to corroborate the results obtained by flow cytometry using another independent approach. A sensitive RT-PCR based method that we have previously used for analyzing TCR- $\gamma \delta$ repertoire analysis in human fetal tissues $(24,25)$ was used for this purpose. The assay uses oligonucleotide primers specific for $\mathrm{V} \delta 1, \mathrm{~V} \delta 2$, or $\mathrm{V} \delta 3$, in combination with a $\mathrm{C} \delta$ gene segment primer to amplify cDNA generated from mRNA samples using reverse transcriptase. After gel electrophoresis the products of amplification were excised from the gel, and equivalent amounts used as a template for a second ampli- fication using the same forward $\mathrm{V} \delta$ primer and a reverse-primer specific for each of the four human $\mathrm{J} \delta$ genes. In establishing this assay, individual V $\delta 1-J \delta 1-4, \mathrm{~V} \delta 2-\mathrm{J} \delta 1-4$, and $\mathrm{V} \delta 3-\mathrm{J} \delta 1-4$ receptor cDNA clones were used to determine the optimum conditions for the proportional amplification of $\mathrm{V} \delta$-J $\delta$ genes; there was no cross-priming. The products of this second amplification were then electrophoresed on $1.8 \%$ agarose gels, Southern blotted, and hybridized with $\left[\gamma^{32} \mathrm{P}\right]-$ ATP end-labeled V $\delta 1, V \delta 2$, or $V \delta 3$ oligonucleotide probes containing sequence internal to the $\mathrm{V} \delta$ primers used for PCR.

This assay was first used to analyze samples of intestine from noninvolved and involved seg- 


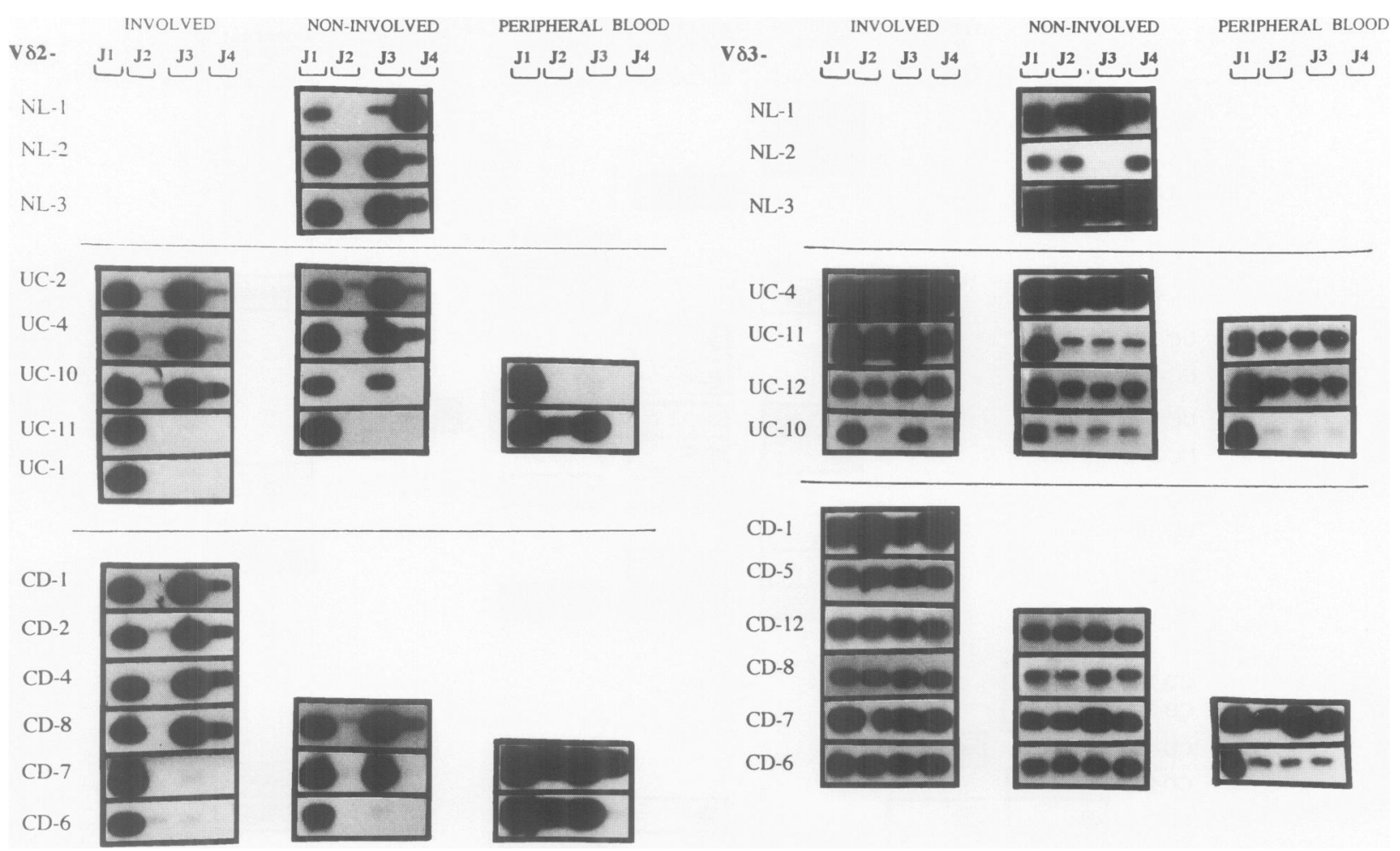

FIG. 3. Profile of $\mathrm{V} \delta 2-\mathrm{J} \delta$ and $\mathrm{V} \delta 3-\mathrm{J} \delta$ TCR expression in surgical samples of noninvolved and involved intestine of individual patients with CD, UC, or normal (NL) mucosa from colon cancer patients RT-PCR was carried out as described in Fig. 2-using ${ }^{32} \mathrm{P}$-labeled oligonucleotide probes complimentary to V $\delta 2$ or $\mathrm{V} \delta 3$. Autoradiography was carried out for $24 \mathrm{hr}$.

ments of tissue obtained from 20 patients with IBD for $\mathrm{V} \delta$-J $\delta$ receptor expression. Ten patients diagnosed with UC (1-16 in Table 1), seven with CD (17-28 in Table 1), and three patients with diverticular disease (diverticulitis, 29-31 in Table 1) were used as a source of involved and noninvolved mucosal mRNA. In addition, tissue from the normal margins of colonic mucosa from three colon cancer patients (32-34 in Table 1) were also used as noninvolved, "normal" controls. The results of this analysis shown in Fig. 2 identify changes in the pattern of $\mathrm{V} \delta 1-\mathrm{J} \delta$ expression in the involved mucosa compared to the noninvolved mucosa and blood of IBD patients. The $\mathrm{V} \delta$-J $\delta$ profile of the noninvolved colonic mucosa (* profiles in Fig. 2) was characterized by expression of receptors encoded by $\mathrm{V} \delta 1-\mathrm{J} \delta 1,2$, and 3 , and by very low levels or an absence of $\mathrm{V} \delta 1-J \delta 4$-encoded receptor chains. This profile was distinct from that of the peripheral blood in which all four $J \delta$-gene segments were utilized by $\mathrm{V} \delta 1$-encoded receptors. By contrast, a single $\mathrm{V} \delta 1$-encoded receptor predominated in the in- volved colonic mucosa. Regardless of whether the involved intestinal tissue was derived from patients with UC, CD, or diverticulitis, V $\delta 1-J \delta 1$ receptor expression predominated and it was the only V $\delta 1$-encoded receptor detected in $13 / 17$ IBD patients and $3 / 3$ patients with diverticular disease. Importantly, this finding agrees with the results obtained by flow cytometry in which $\mathrm{V} \delta 1-\mathrm{J} \delta \mathrm{l}^{+}$cells were the major $\mathrm{V} \delta \mathrm{1}^{+} \gamma \delta \mathrm{T}$ cell population in the involved colonic mucosa (Fig. 1), and it also demonstrates the utility of this procedure for TCR $-\gamma \delta$ repertoire analysis.

DNA sequence analysis of randomly selected $\mathrm{V} \delta 1-\mathrm{C} \delta$ cDNAs from involved and noninvolved mucosal mRNA samples from a patient with UC did not identify any $\mathrm{V} \delta 1$ receptors that were unique to the inflamed colonic mucosa (data not shown). All of the V $\delta 1-T C R-c D N A s$ encoded functional, in-frame receptors consistent with the receptor cDNAs detected by RT-PCR analysis being derived from productively rearranged genes. The $V \delta 1-C \delta$ cDNAs from noninvolved mucosa and $\mathrm{V} \delta 1-\mathrm{C} \delta$ cDNAs from involved mu- 


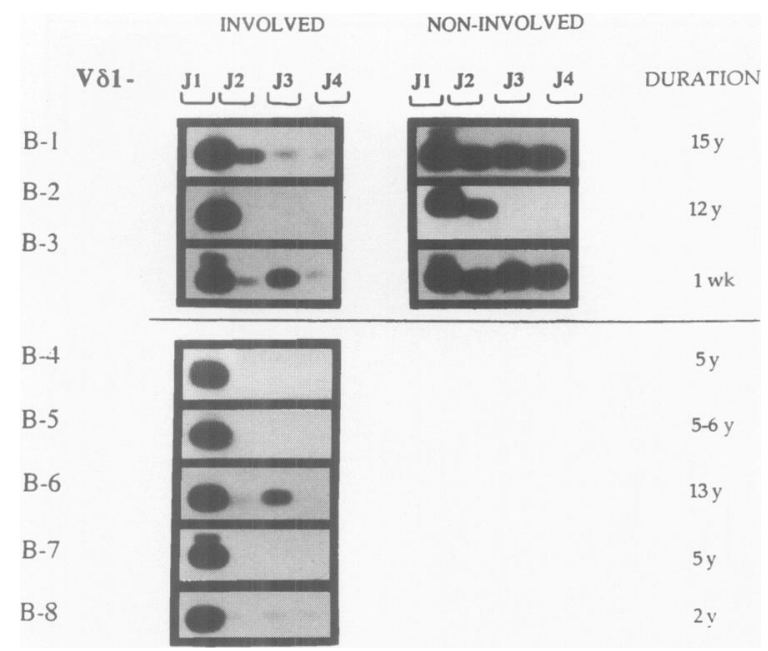

FIG. 4. Profile of Vס1-Jס TCR expression in mucosal biopsy samples of noninvolved and involved intestine of individual patients with colonic UC

PCR was carried out as described in Fig. 2. Autoradiography was carried out for $24 \mathrm{hr}$.

cosa utilized the $J \delta 1$ gene segment, which is consistent with the results from both flow cytometric and RT-PCR analyses. In addition, a single $D$-gene segment, D $\delta 3$, was exclusively used by all of the V $\delta 1$-receptor chains expressed in the noninvolved (33/33) and involved (22/22) mucosa.

Lack of Bias in the Expression of $\mathrm{V} \delta 2$ - and V83-encoded Receptors in Surgical Resected Tissue Specimens of Patients with IBD

We were interested in knowing whether the $V \delta 2$ and $V \delta 3$ receptors, which are similar to $V \delta 1$ encoded receptors, were also biased in $J \delta$ gene usage. Figure 3 shows the $\mathrm{V} \delta 2 / \mathrm{V} \delta 3$ repertoire analysis of 10 IBD patients representative of a total of 20 patient samples analyzed. In the normal intestine, $V \delta 2$ receptors primarily utilized $\mathrm{J} \delta 1$ and $\mathrm{J} \delta 3$ whereas $\mathrm{V} \delta 3$ receptors utilized all four $\mathrm{J} \delta$ gene segments. This profile of $\mathrm{V} \delta 2-\mathrm{J} \delta$ and $\mathrm{V} \delta 3-\mathrm{J} \delta$ expression did not change significantly in the noninvolved intestine or in tissue samples obtained from different regions of the inflamed intestine (data not shown). In 2/16 CD samples and 3/35 UC samples from the inflamed mucosa,
$\mathrm{V} \delta 2-\mathrm{J} \delta 1$ was predominant or was the only receptor expressed. Likewise, in rare samples (i.e., UC10) a bias in the $V \delta 3-J \delta$ expression was also evident. Taken together, our analysis of the TCR-V $\delta$ repertoire in the colonic mucosa demonstrates that a single $\mathrm{V} \delta$ receptor, $\mathrm{V} \delta 1-\mathrm{J} \delta 1$, predominates in the inflamed mucosa of patients with CD and UC.

\section{Bias in Expression of $\mathrm{V} \delta 1$-encoded Receptors by $\gamma \delta \mathrm{T}$ Cells in Biopsy Tissue Specimens}

The RT-PCR assay was next applied to the analysis of colonic mucosal tissue biopsy samples to determine if changes in $\gamma \delta \mathrm{T}$ cell repertoire detected in patients with severe disease were present in patients with newly diagnosed and/or less severe forms of IBD (Table 2). Because of the small size of the mucosal tissue samples procured by sigmoidoscopy and colonoscopy, it is not normally possible to isolate sufficient numbers of cells for fluorescenceactivated cell sorting (FACS) analysis. The samples obtained from eight UC patients (Table 2) were therefore processed for RNA isolation and RT-PCR analysis of TCR-V $\delta$-J $\delta$ expression. The results of this analysis shown in Fig. 4 clearly identify V $\delta 1$ $\mathrm{J} \delta 1$ receptor expression as being the predominant receptor expressed in all of the patient samples. In five of eight patient samples it was the only $\mathrm{V} \delta 1-\mathrm{J} \delta$ TCR- $\delta$ chain expressed. Interestingly, this receptor was also predominant in the mucosa of a newly diagnosed UC patient who had symptoms of disease for less than 2 weeks. The expression of other $\mathrm{V} \delta 1$-J $\delta$-encoded receptors in noninvolved samples strongly suggests that the predominance of $\mathrm{V} \delta \mathrm{I}$ $J \delta 1$ receptor expression in the involved mucosa was not due to a PCR-related artifact.

In summary, our cellular and molecular analyses of $\gamma \delta \mathrm{T}$ cells in the colonic mucosa of patients with IBD has shown that these cells accumulate in large numbers at the site of inflammation and tissue injury and can be distinguished by expression of a TCR- $\delta$ chain encoded by $\mathrm{V} \delta 1-\mathrm{J} \delta 1$ gene segments. These changes were apparent in all the IBD patients we analyzed, irrespective of the form or stage and severity of disease. To begin to understand the significance of these changes in the mucosal $\gamma \delta$ T cell repertoire for the disease process in IBD, subsequent experiments were designed to analyze the effector function of mucosal $\gamma \delta$ T cells. 
A

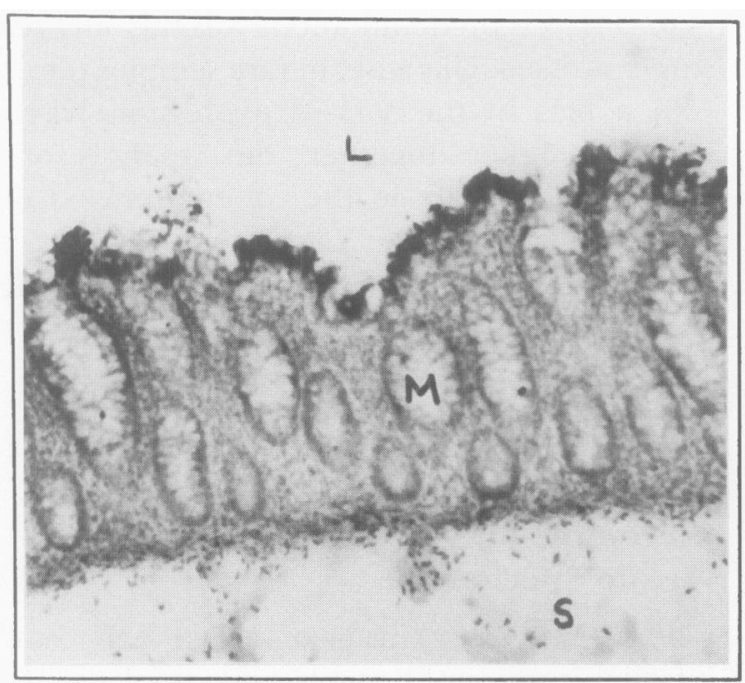

C

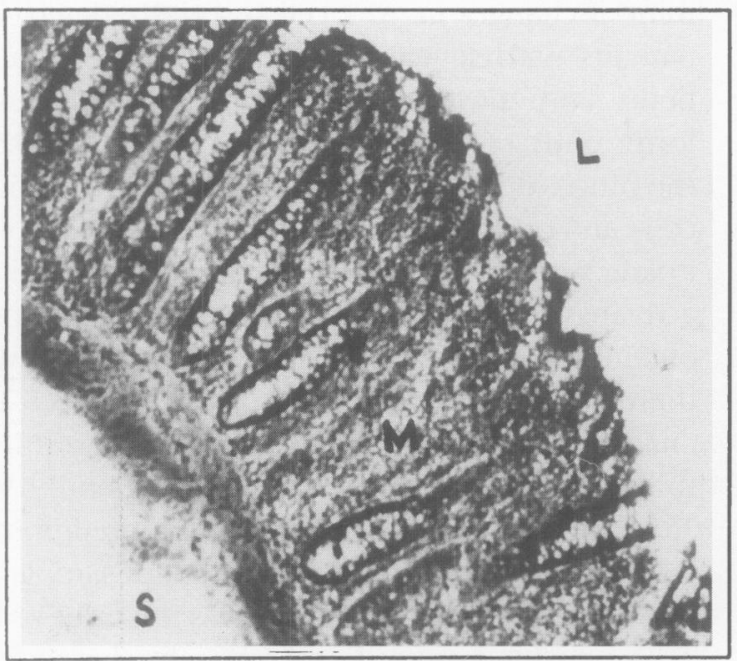

E

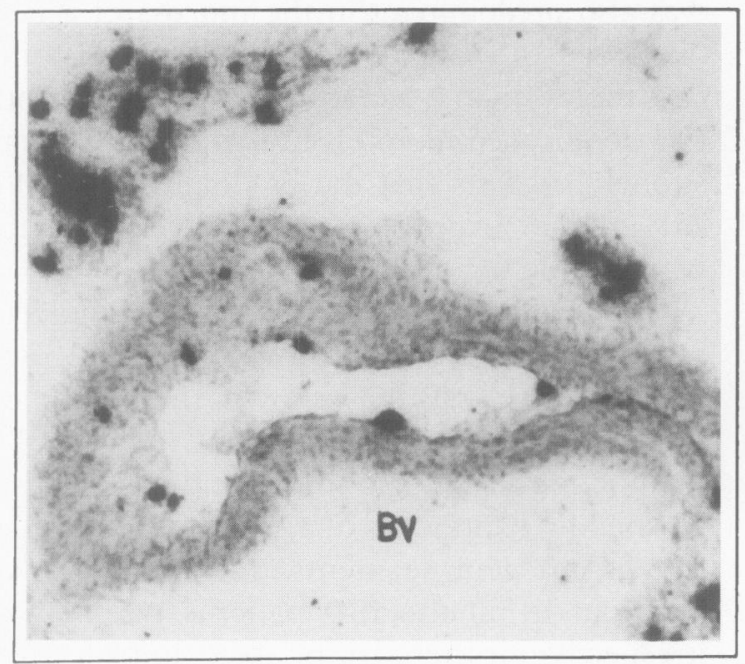

B

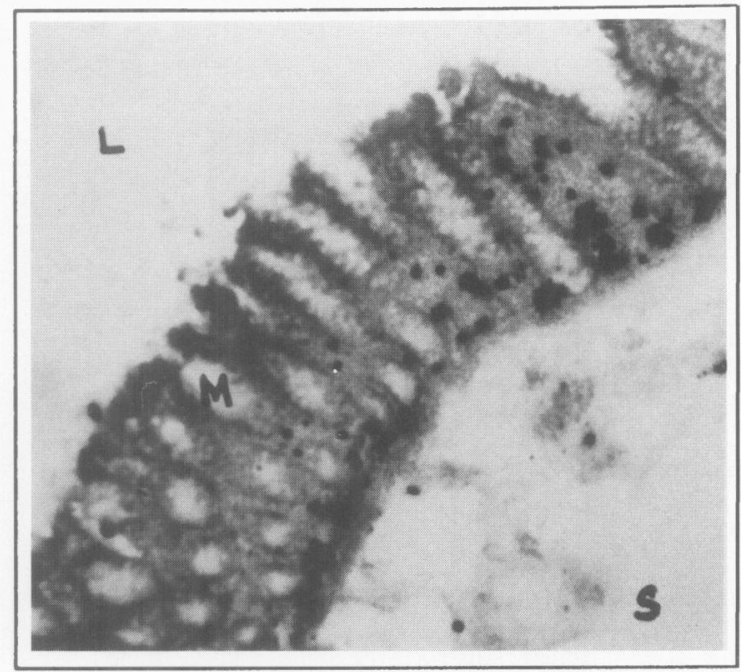

D
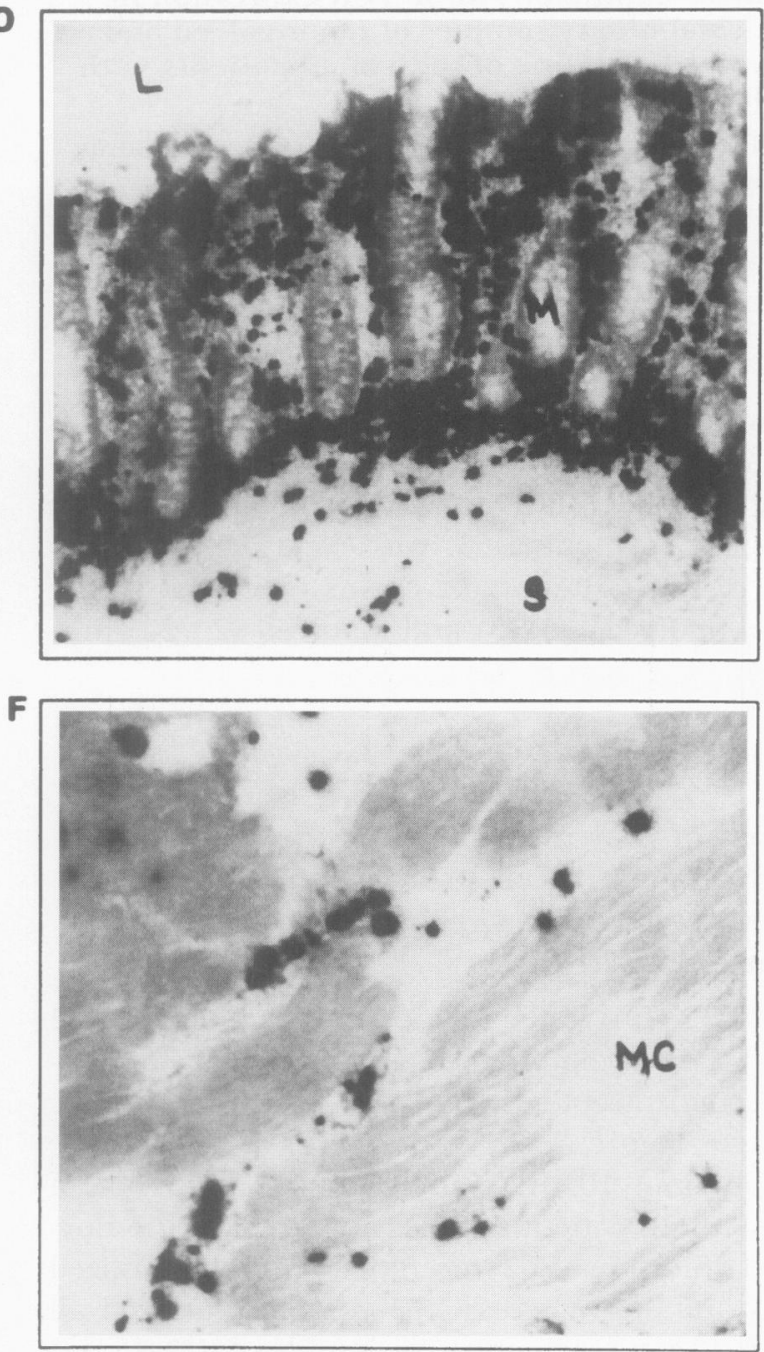

FIG. 5. In situ hybridization analysis of IFN- $\gamma$ gene expression in sections of noninvolved or involved areas of colon from CD patient, CD-1

(A) Noninvolved tissue, sense RNA probe. (B) Noninvolved tissue, anti-sense RNA probe. (C) Involved tissue, sense RNA probe. (D-F) Involved tissue, anti-sense RNA probe. L, lumen; M, mucosa; S, submucosa; BV, blood vessel; MC, muscle. 
TABLE 3. IFN- $\gamma$ production by lamina propria $T$ cells in the normal and diseased colon

\begin{tabular}{|c|c|c|c|c|}
\hline \multirow{2}{*}{$\begin{array}{l}\text { T Cell } \\
\text { Population }^{a}\end{array}$} & & \multirow[b]{2}{*}{$\%$ mRNA $^{+}$Cells $^{b}$} & \multicolumn{2}{|c|}{$\mathbf{U} / \mathbf{m l}$} \\
\hline & & & Media & anti-CD3 \\
\hline \multicolumn{5}{|c|}{ CD Patient \#1 (Ileocolonic) } \\
\hline \multirow[t]{2}{*}{ Total } & $\mathbf{N}$ & $12 \pm 4$ & $<5$ & $39 \pm 8$ \\
\hline & I & $39 \pm 5$ & 5 & $99 \pm 10$ \\
\hline \multirow[t]{2}{*}{$\alpha \beta^{+} \mathrm{T}$ cells } & $\mathrm{N}$ & $10 \pm 2$ & $10 \pm 2$ & $38 \pm 10$ \\
\hline & I & $46 \pm 10$ & $9 \pm 3$ & $53 \pm 14$ \\
\hline \multicolumn{5}{|l|}{$\gamma \delta^{+} \mathrm{T}$ cells } \\
\hline$\left(9 \% \mathrm{~V} \delta 1^{+}\right)$ & $\mathrm{N}$ & $16 \pm 4$ & $7 \pm 6$ & $19 \pm 2$ \\
\hline$\left(35 \% \mathrm{~V} \delta 1^{+}\right)$ & I & $39 \pm 5$ & $12 \pm 4$ & $109 \pm 5$ \\
\hline \multicolumn{5}{|c|}{ CD Patient \#2 (Ileocolonic) } \\
\hline \multirow[t]{2}{*}{ Total } & $\mathbf{N}$ & $15 \pm 3$ & $8 \pm 9$ & $13 \pm 2$ \\
\hline & I & $61 \pm 6$ & $7 \pm 7$ & $78 \pm 9$ \\
\hline \multirow[t]{2}{*}{$\alpha \beta^{+} \mathrm{T}$ cells } & $\mathrm{N}$ & $11 \pm 5$ & $6 \pm 6$ & $23 \pm 5$ \\
\hline & I & $56 \pm 8$ & $13 \pm 11$ & $57 \pm 8$ \\
\hline \multicolumn{5}{|l|}{$\gamma \delta^{+} \mathrm{T}$ cells } \\
\hline$\left(12 \% \mathrm{~V} \delta 1^{+}\right)$ & $\mathbf{N}$ & $17 \pm 9$ & $11 \pm 8$ & $18 \pm 13$ \\
\hline$\left(53 \% \mathrm{~V} \delta 1^{+}\right)$ & I & $38 \pm 7$ & $24 \pm 10$ & $165 \pm 11$ \\
\hline \multicolumn{5}{|c|}{ CD Patient \#3 (Colonic CD) } \\
\hline \multirow[t]{2}{*}{ Total } & $\mathrm{N}$ & $11 \pm 6$ & $<5$ & $59 \pm 17$ \\
\hline & I & $35 \pm 10$ & $43 \pm 19$ & $78 \pm 21$ \\
\hline \multirow[t]{2}{*}{$\alpha \beta^{+} \mathrm{T}$ cells } & $\mathrm{N}$ & $29 \pm 5$ & $18 \pm 9$ & $39 \pm 6$ \\
\hline & I & $39 \pm 7$ & $33 \pm 11$ & $54 \pm 10$ \\
\hline \multicolumn{5}{|l|}{$\gamma \delta^{+} \mathrm{T}$ cells } \\
\hline$\left(15 \% \mathrm{~V} \delta 1^{+}\right)$ & $\mathrm{N}$ & $9 \pm 3$ & $12 \pm 8$ & $35 \pm 12$ \\
\hline$\left(43 \% \mathrm{~V} \delta 1^{+}\right)$ & I & $66 \pm 8$ & $34 \pm 15$ & $177 \pm 21$ \\
\hline
\end{tabular}

${ }^{a}$ Nonfractionated (total) T cells and purified populations of $\alpha \beta^{+}$and $\gamma \delta^{+}$cells were isolated from segments of noninvolved (N) and involved (I) colonic mucosa. Frequency of $\mathrm{V} \delta \mathrm{l}$-expressing cells in $\gamma \delta \mathrm{T}$ cell preparations is shown in parentheses.

${ }^{b}$ Frequency of cells that after hybridization in situ with anti-sense probe were overlayed with more than 5 grains.

\section{Mucosal $\gamma \delta$ T Cells Are a Major Source of IFN- $\boldsymbol{\gamma}$ Production in IBD}

Since IFN- $\gamma$ production appears to be an important mediator of the inflammatory process and tissue injury in patients with IBD (31) and is involved in the pathogenesis of intestinal inflammation in animal models of IBD (32), we investigated whether $\gamma \delta \mathrm{T}$ cells in the intestinal mucosa of patients with IBD were a source of IFN- $\gamma$. In situ hybridization analysis of IFN- $\gamma$ mRNA expression in tissue sections from involved or normal intestinal mucosal tissue (Fig. 5) showed that the IFN- $\gamma$ gene was constitutively expressed at low levels by cells in the normal, noninvolved, mucosa. By contrast, in sections of involved colonic tissue from a $C D$ patient (CD-1), the number of IFN- $\gamma$-mRNA ${ }^{+}$cells was greatly increased (Fig. 5D). No hybridization signal was detected in sections probed with a control sense probe (Fig. 5A and $\mathrm{C}$ ). The distribution of IFN- $\gamma$ mRNA $^{+}$cells in diseased mucosa (Fig. 5D) was similar to that of TCR $-\delta^{+}$mRNA-expressing cells (data not shown), suggesting $\mathrm{T}(\gamma \delta)$ cells as a likely source of IFN- $\gamma$ production. In addition, the identification of IFN- $\gamma$ $\mathrm{mRNA}^{+}$cells in blood vessels in the submucosa (Fig. 5E) and muscle (Fig. 5F) was consistent with 

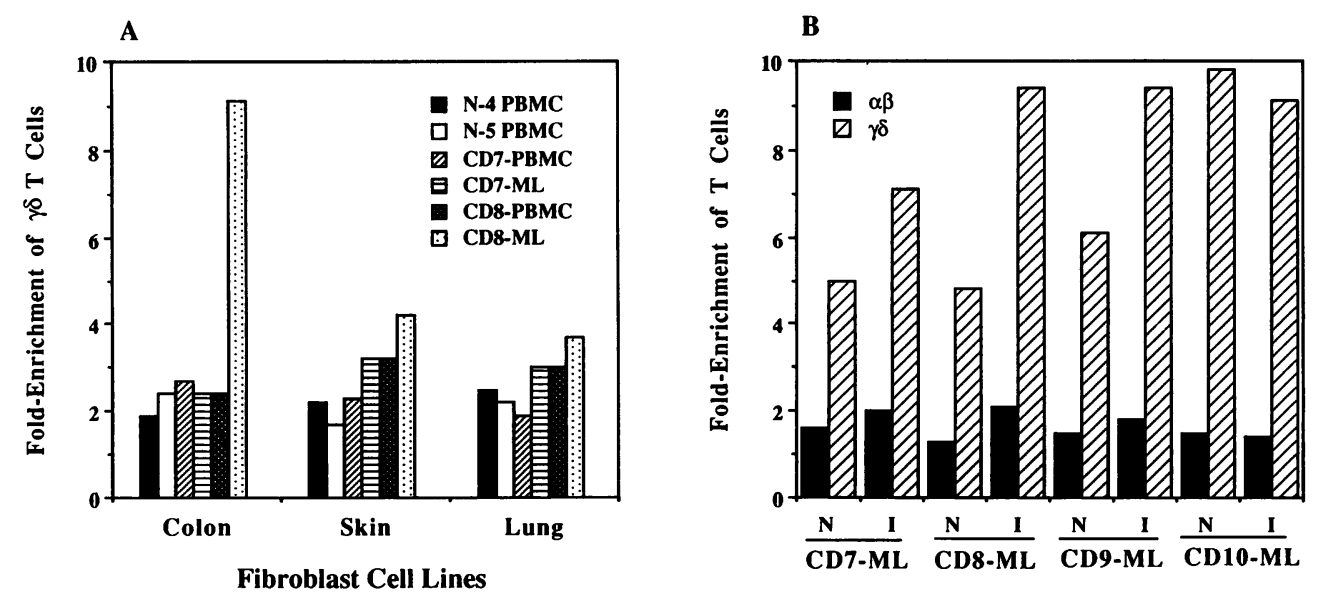

FIG. 6. Enrichment of $\gamma \delta \mathrm{T}$ cells among peripheral blood (PB) and colonic mucosal (ML) T cells by adherence to fibroblast cell lines

(A) Selective adherence of $\gamma \delta \mathrm{T}$ cells to fibroblast cell lines of intestinal origin. $\mathrm{T}$ cells isolated from the blood of normal healthy donors (N-PB) and CD patients (CD-PB) and from segments of inflamed (involved) colon from CD patients $(\mathrm{CD}-\mathrm{ML})$ were co-cultured with different established fibroblast cell lines for $30 \mathrm{~min}$ at $37^{\circ} \mathrm{C}$. The fold-enrichment of $\gamma \delta$ $\mathrm{T}$ cells among the adherent cells was determined by comparing the number of $\gamma \delta \mathrm{T}$ cells in the input and adherent fraction, the values for which were obtained by staining with anti-TCR antibodies and flow cytometry. (B) Preferential adherence of mucosal $\gamma \delta \mathrm{T}$ cells to colonic fibroblasts. Colonic T cells isolated from segments of involved (I) and noninvolved $(\mathrm{N})$ colon from the same $\mathrm{CD}$ patient were cultured with the colonic fibroblast cell line, CCD-18Co, for 30 min. Fold-enrichment of adherent $\alpha \beta$ and $\gamma \delta$ T cells was determined by flow cytometry.

the transmural distribution of TCR- $\delta$-mRNA ${ }^{+}$cells (data not shown).

To identify the cellular source(s) of IFN- $\gamma$ production in the colonic mucosa, IFN- $\gamma$-gene expression and protein secretion was analyzed in isolated populations of $\gamma \delta$ and $\alpha \beta$ LP T cells. These $\mathrm{T}$ cell populations were isolated from the mononuclear cell fraction of noninvolved and involved mucosa from three patients with $C D$ using immunomagnetic selection. The isolated populations were routinely $>95 \% \mathrm{CD}^{+}$and the degree of contamination of the $\gamma \delta$ fraction by $\alpha \beta^{+}$cells and the $\alpha \beta$ fraction by $\gamma \delta^{+}$cells was routinely $<10 \%$ (data not shown). As seen in our previous flow cytometric analyses of mucosal $\mathrm{T}$ cells (Fig. 1A), $\mathrm{V} \delta \mathrm{I}^{+}$cells were the major $\gamma \delta \mathrm{T}$ cell subset $(67 \pm 8 \%)$ in the involved mucosa compared with the noninvolved mucosa (12 \pm $2 \%)$. The increase in the number of $\mathrm{T}$ cells in the LP of involved mucosa (see above) was paralleled by an increase in the frequency of cells that constitutively expressed IFN- $\gamma$-mRNA (Table 3 ). This was particularly apparent for $\gamma \delta \mathrm{T}$ cells that contained a higher proportion of $\mathrm{mRNA}^{+}$cells than $\alpha \beta$ T cells. The analysis of IFN- $\gamma$ secretion was consistent with the mRNA analysis and demonstrated that $\gamma \delta \mathrm{T}$ cells, including $\mathrm{V} \delta 1^{+}$ cells, were a major source of this proinflamma- tory cytokine in the involved mucosal CD samples analyzed.

\section{Selective Interaction of $\boldsymbol{\gamma} \delta \mathrm{T}$ Cells with Colonic Fibroblasts}

In view of the accumulation of $\gamma \delta$ T cells, particularly $\mathrm{V} \delta 1^{+}$cells, in the LP of the involved intestinal mucosa of $C D$ patients and results from previous studies demonstrating that $\gamma \delta$ T cells can interact with stromal cells in other tissues such as skin $(9,33)$, we determined if mucosal $\gamma \delta$ $\mathrm{T}$ cells, particularly $\mathrm{V} \delta \mathrm{I}^{+}$cells, from patients with IBD could adhere to and interact with colonic stromal cells, and fibroblasts in particular. To accomplish this we took advantage of the availability of established and well-characterized fibroblast cell lines of different mucosal tissue origin and the $\gamma \delta \mathrm{T}$ cell-skin fibroblast adherence assay described by White and co-workers (9). To date, the possibility that $\gamma \delta \mathrm{T}$ cells can interact with colonic stromal cells such as fibroblasts and how this interaction might be affected during IBD has not been investigated. Bulk populations of colonic $\mathrm{T}$ cells isolated from segments of normal and involved tissue of individual IBD patients were briefly incubated with confluent monolayers of fibroblasts and the composition 
A

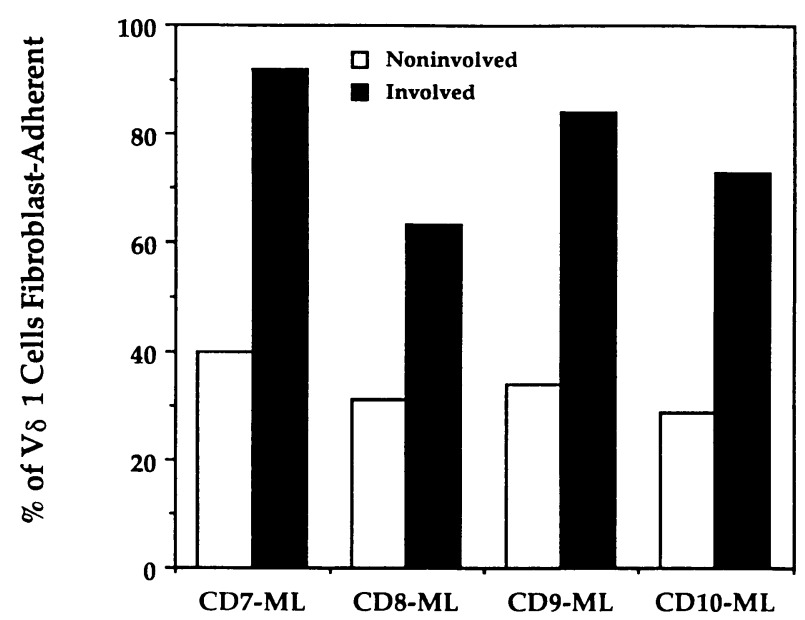

B

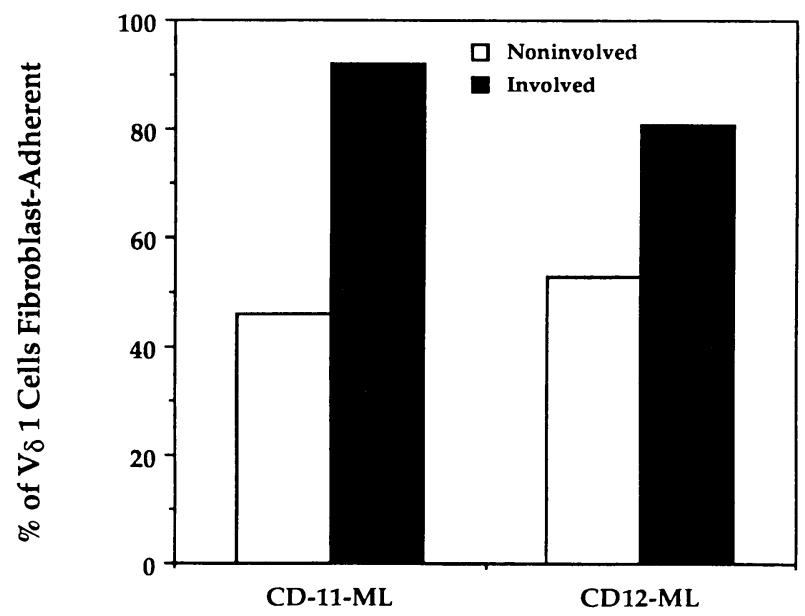

FIG. 7. Predominance of fibroblast-adherent $V \delta 1^{+} \gamma \delta \mathrm{T}$ cells in the inflamed colonic mucosa

Colonic T cells isolated from segments of involved and noninvolved colon of CD patients were co-cultured for 30 min with the established colonic fibroblast cell lines CCD-18Co (A) or a primary colonic fibroblast cell line obtained from involved mucosa of CD Patient $\mathrm{ll}$ (B). The proportion of $\mathrm{V} \delta \mathrm{l}^{+}$fibroblast-adhering cells was determined from the number of $\mathrm{V} \delta \mathrm{I}^{+}$cells in the input and adherent cell populations by flow cytometry.

and phenotype of adherent and nonadherent cells determined by flow cytometry.

As seen in Fig. 6A, mucosal $\gamma \delta \mathrm{T}$ cells from one of two patients with CD (CD8) were considerably enriched for after $\mathrm{Co}$-culture with colonic fibroblasts. Whereas co-culture with skin- or lung-derived fibroblasts produced between 1.5and 3.5-fold enrichment of $\gamma \delta \mathrm{T}$ cells, culture with the colonic fibroblast cell line CCD-18Co resulted in an almost 10 -fold enrichment of $\gamma \delta \mathrm{T}$ cells. A similar level of $\gamma \delta$ T cell enrichment was also seen using another colonic fibroblast cell line (CCD-112Con) (data not shown), excluding the possibility that the interaction with the CCD$18 \mathrm{Co}$ cell line was due to some peculiar property of this cell line. Analysis of nonadherent T cells from cultures with colonic fibroblasts showed a reciprocal decrease in the $\gamma \delta \mathrm{T}$ cells (data not shown), excluding the trivial explanation that their enrichment was due to preferential survival during or after culture. The specificity of mucosal $\gamma \delta$ T cell-fibroblast interaction was also demonstrated by the failure to see a similar enrichment of $\gamma \delta \mathrm{T}$ cells using peripheral blood from two of the same CD patients, or using fibroblasts derived from sources other than the colon. Enrichment of $\alpha \beta$ T cells among adherent cells after co-culture with colonic fibroblasts, or fibroblasts of other tissue origin (data not shown), was 2 -fold or less (Fig. 6B), which suggests that increased adhesiveness of $\gamma \delta \mathrm{T}$ cells reflects an inherent property of these cells rather than a function of the fibroblast monolayer. Slightly higher levels of $\gamma \delta \mathrm{T}$ cell enrichment were seen using lymphocytes from the involved versus noninvolved mucosa with three of the four patients with $\mathrm{CD}$ (Fig. 6B).

Analysis of the fibroblast-adherent $\gamma \delta$ T cells showed that the majority of those isolated from the noninvolved $(75 \% \pm 8 \%)$ and involved $(84 \% \pm 9 \%)$ mucosa of four patients

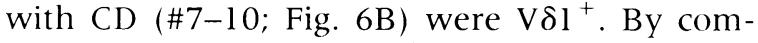
paring the number of ${\mathrm{V} \delta 1^{+}}^{+}$cells in the input and adherent cell populations it was possible to determine what proportion of these cells in the noninvolved versus involved mucosa of the same patient were fibroblast-adherent (Fig. 7A). Whereas in the noninvolved mucosa fibroblastadherent $\mathrm{V} \delta 1$ cells represented $<40 \%$ (mean of $31 \%$ with a range of $24 \%$ to $39 \%$ ) they represented almost $80 \%$ (mean of $78 \%$ with a range of $63 \%$ to $92 \%$ ) of ${\mathrm{V} \delta 1^{+}}^{+}$cells in the involved mucosa. Thus, the accumulation of ${\mathrm{V} \delta 1^{+}}^{+} \delta \delta \mathrm{T}$ cells in the inflamed mucosa of patients with IBD was associated with an increase in their ability to interact and adhere to colonic fibroblasts. Using a primary colonic fibroblast cell line derived from mucosal tissue sample from a patient with primary colonic CD (Fig. 7B), we have reproduced the results obtained using established colonic fi- 
broblast cell lines. In particular, using either donor-matched or allogeneic LP lymphocytes from noninvolved or involved mucosa as input cells, a higher proportion of ${\mathrm{V} \delta 1^{+}}^{+}$cells from the involved mucosa $(88 \% \pm 6 \%)$ were fibroblastadherent compared with those from the noninvolved mucosa $(47 \% \pm 5 \%)$.

\section{DISCUSSION}

We have compared the phenotypic and functional characteristics of $\gamma \delta \mathrm{T}$ cells within the normal and inflamed colonic mucosa of a large number of patients with IBD. Our results demonstrate that the chronic inflammatory immune response that occurs in the colon of IBD patients is associated with distinct changes in the number, distribution, composition, and function of mucosal $\gamma \delta \mathrm{T}$ cells. The size of the $\gamma \delta \mathrm{T}$ cell population in the diseased mucosa was significantly increased and could be attributed to an increase in ${\mathrm{V} \delta \mathrm{I}^{+}}^{+} \delta \delta \mathrm{T}$ cells, among which, cells that expressed a TCR $\delta$-chain encoded by $\mathrm{V} \delta 1-\mathrm{J} \delta 1$ gene segments predominated. These changes in mucosal $\gamma \delta$ T cells were not restricted to individual patients or a particular group of patients with IBD but were present in the majority of UC, CD, and diverticulitis patient samples that we analyzed. The predominance of $\mathrm{V} \delta 1-\mathrm{J} \delta 1$ receptorbearing cells was seen in patients with advanced forms of disease who required surgery and in biopsy samples obtained from patients with less severe forms of IBD, as well as in a patient that had clinical signs of disease for less than 2 weeks. Among $\mathrm{T}$ cells present in the inflamed mucosa of patients with $C D, \gamma \delta \mathrm{T}$ cells were a major source of the proinflammatory cytokine IFN- $\gamma$ and were enriched for $\mathrm{V} \delta 1^{+} \gamma \delta \mathrm{T}$ cells that could selectively interact with colonic fibroblasts. Although it was not possible to determine if these changes in the properties of mucosal $\gamma \delta$ cells were primary abnormalities of these disorders, they are consistent with, and suggest that they contribute to, the pathophysiology of IBD.

The results of our studies contrast with those obtained previously from the immunohistochemical analysis of $\gamma \delta$ T cells in colonic tissue sections obtained from IBD patients in which a decrease (17) or no change (16) in the number of TCR $-\delta^{+}$cells was reported. A likely explanation for the apparent discrepancy between these two studies and our own is the different techniques used. The immunohistochemical detection of $\mathrm{T}$ cells in intestinal tissue is difficult to perform and is a relatively insensitive means of detecting antigens such as the $\gamma \delta$ TCR that are expressed at low levels $(28,29)$. In addition, since the relative number of $\gamma \delta \mathrm{T}$ cells within the intestinal mucosa has been shown to vary greatly, not only between different sections of the same tissue but also between sections of the same site originating from different subjects (29), estimates of their relative number based upon this technique alone are unlikely to be accurate. Finally, since the degree of inflammatory activity may also significantly influence the distribution of $\gamma \delta \mathrm{T}$ cells in the diseased colon, variation among individual patients with IBD may also account for some of the contrasting results obtained from the different studies.

The increase in $V \delta 1$-expressing $\gamma \delta \mathrm{T}$ cells in the LP of the inflamed colon of IBD patients may represent the expansion of resident and/or infiltrating cells from the blood. Since there are currently no phenotypic markers, including CD8, that can unambiguously discriminate between intestinal and blood-derived $V \delta \mathbf{l} \gamma \delta \mathrm{T}$ cells, it is not possible to definitively identify the origin of $\mathrm{V} \delta 1^{+}$cells within the LP of patients with IBD. However, several pieces of evidence suggest that a large number of these cells are derived from the peripheral blood. The phenotype of $\mathrm{LP} \mathrm{V} \delta 1^{+}$ $\left(\mathrm{CD}^{-}\right)$cells in IBD patients is similar to that of those normally found in the blood (34) and resembles the phenotype of blood-derived $\gamma \delta \mathrm{T}$ cells that possess transendothelial migratory properties and accumulate within tissues at sites of inflammation (10). Interestingly, Chowers and colleagues (35) have recently shown that, on the basis of the presence of unique junctional sequences of TCRs expressed by intestinal $\gamma \delta \mathrm{T}$ cells, it is possible to distinguish between $\mathrm{V} \delta \mathrm{l}^{+}$ cells normally resident in the blood and intestine.

Irrespective of the origin of the $\mathrm{V} \delta 1^{+} \gamma \delta \mathrm{T}$ cells that accumulate in the colonic mucosa of IBD patients, an important question that remains to be addressed is the nature of the stimulus that drives their expansion. The oligoclonal nature and limited structural diversity of the intestinal $V \delta 1$ repertoire in the normal intestine (35) suggest that the array of ligands recognized by these receptors is limited. There are three possible sources of these ligands in the inflamed colon of IBD patients. The first is that they are enteric (bacterial and food) antigens that mucosal $\mathrm{V} \delta \mathrm{I}^{+}$ $\gamma \delta \mathrm{T}$ cells could be exposed to as a result of them being able to cross the epithelial barrier of the 
intestinal wall, which is disrupted as part of the disease process in IBD. The recent observation that $E$. coli and $P$. aeruginosa, which normally inhabit the gastrointestinal tract, can stimulate $\mathrm{V} \delta 1$-bearing peripheral blood $\gamma \delta \mathrm{T}$ cells (36) is consistent with this possibility. Furthermore, the finding that gut $\mathrm{T}$ cells from patients with IBD proliferate vigorously to preparations of their own flora (37) suggests that a breakdown in the mechanisms that normally operate to maintain $\mathrm{T}$ cell hyporesponsiveness ("oral tolerance") to enteric antigens is an important pathogenetic mechanism of IBD. A second possibility is that the antigens are endogenously derived and are expressed by stressed or damaged epithelial cells. The selective accumulation of ${\mathrm{V} \delta 1^{+}}^{+} \delta \mathrm{T}$ cells in the IE spaces of the intestine has long been interpreted as evidence for an immune surveillance role for these cells in which they recognize and react with a common antigen, such as heat shock proteins (HSP), expressed by epithelial cells as a result of infection, damage, or transformation (38). To date, however, recognition of self-antigens such as HSP by $\gamma \delta \mathrm{T}$ cells has only been demonstrated for cells that utilize a receptor encoded by the $\mathrm{V} \delta 2$ and $\mathrm{V} \gamma \boldsymbol{9}$ gene segments $(39,40)$. Extensive epithelial cell damage could, however, enable IEL such as V $\delta 1^{+}$cells to "leak" into the LP, thus contributing to the increase in the number of ${\mathrm{V} \delta 1^{+}}^{+}$cells seen in the LP of IBD patients. The third possibility is that the activation of $\mathrm{V} \delta \mathrm{l}$-expressing $\gamma \delta \mathrm{T}$ cells is antigen-independent and does not involve the TCR/CD3 complex. The existence of alternative, antigenindependent pathways of mucosal $\mathrm{T}$ cell activation is suggested by the finding that LP T cells, unlike peripheral blood T cells, from normal and IBD patients exhibit vigorous proliferative responses via the $\mathrm{CD} 2 / \mathrm{CD} 28$ signaling pathway (41-45). The presence in the inflamed mucosa of large numbers of activated $\mathrm{T}$ cells that produce cytokines (46-49) could also serve to activate, in a "bystander" manner, $\mathrm{V} \delta \mathrm{I}^{+}$cells $(50)$, as well as to maintain a population of chronically activated $\mathrm{T}$ cells within the mucosa.

The $\gamma \delta \mathrm{T}$ cells that accumulate in the inflamed mucosa of patients with $C D$ possess two functional characteristics that are relevant to the pathophysiology of this IBD. The first is that they are a major source of the proinflammatory cytokine IFN- $\gamma$, which has long been shown to mediate epithelial cell injury (51). Although the constitutive production of IFN- $\gamma$ by colonic lymphocytes from IBD patients has been previously reported $(44,49,51)$, our analysis identifies $\gamma \delta \mathrm{T}$ cells, including $\mathrm{V} \delta 1^{+}$cells, as a source of this cytokine in situ in the inflamed mucosa, and suggests a means by which they might contribute to the chronic inflammatory immune reaction and tissue injury in $\mathrm{CD}$. The second characteristic is the selective adherence and interaction of mucosal $\gamma \delta \mathrm{T}$ cells, particularly $\mathrm{V} \delta \mathrm{I}^{+}$cells, with intestinal-derived fibroblasts. Although uncontrolled fibroblast proliferation, excessive collagen secretion, and fibrosis cause severe tissue damage and are important complications of $\mathrm{CD}(52,53)$, the processes regulating normal fibroblast activity are poorly understood. One way in which the activity of fibroblasts and other stromal cells could be regulated and coordinated is through direct interactions with other cells, such as $\mathrm{V} \delta \mathrm{1}^{+}$ $\gamma \delta \mathrm{T}$ cells. The production by $\gamma \delta \mathrm{T}$ cells of tumor necrosis factor $\alpha$ (TNF- $\alpha$ ), IL $1-\beta$, and transforming growth factor $\beta$ (TGF- $\beta$ ) (54) that can promote fibroblast growth and collagen synthesis (55), and the observation that epithelial-associated $\gamma \delta \mathrm{T}$ cells in the skin can influence the activity of keratinocytes by the production of keratinocyte cell growth factor (8) are all consistent with this hypothesis. This immunoregulatory property of $\gamma \delta \mathrm{T}$ cells is further substantiated by the results from a variety of animal models of infectious disease in which the ability of $\gamma \delta \mathrm{T}$ cells to influence the activity of other cell populations and the outcome of inflammatory immune responses has been demonstrated (56-61). Since it has previously been shown that fibroblasts can prolong the survival of $\mathrm{T}$ cells in culture after the removal of IL-2 and antigen (62), fibroblast adherence may also provide a means of localizing or retaining activated, peripheral blood-derived, ${\mathrm{V} \delta 1^{+}}^{+}$cells in the inflamed colon. Although we do not yet have an explanation for the differences in $\gamma \delta \mathrm{T}$ cell subsets adhering to colonic fibroblasts, it could be related to quantitative and/or qualitative changes in the expression of adhesion/integrin molecules such as LFA-1 and VLA- 5 by $V \delta 1^{+}$ cells $(9,33,63)$ and their reciprocal receptors, ICAM-1 and fibronectin, respectively, by fibroblasts $(9,33)$. The preferential association of $\mathrm{V} \delta 1^{+} \gamma \delta \mathrm{T}$ cells with fibroblasts provides a possible explanation for their accumulation in the lungs (64) and joints (65-69) in sarcoidosis and rheumatoid arthritis patients, respectively. Interestingly, inflammatory disorders of the lung, joints, skin, and eye are often present as extraintestinal manifestations of IBD (70), raising the possibility that ${\mathrm{V} \delta 1^{+}}^{+}$cells activated in the gut could migrate to other extraintestinal sites 
where, as a result of their ability to interact with fibroblasts or other connective tissue elements, they accumulate and can contribute to the inflammatory immune reaction and inflammation at these sites.

In summary, we have demonstrated that the chronic inflammatory reaction and tissue injury that occurs in the colon of patients with IBD is associated with distinct changes in the number, distribution, composition, and effector function of mucosal $\gamma \delta \mathrm{T}$ cells, particularly $\mathrm{V} \delta \mathrm{I}$-expressing cells. These findings suggest that these cells contribute to at least some of the immunological and pathological changes present in the inflamed mucosa of patients with IBD, and particularly $C D$.

\section{ACKNOWLEDGMENTS}

We are grateful to Ms. Linda Hurd for compiling pertinent data on IBD and normal patients in this study. We thank William G. Crowley for expert technical assistance. This work was supported by grants from the American Cancer Society (JFRA 399) and the National Institutes of Health (AI 31972) to S.R.C. L.D.M. was supported in part by a National Institutes of Health Training Grant (5-T32-CA-09140-20) and a Crohn's and Colitis of America (CCFA) Fellowship.

\section{REFERENCES}

1. Strober W, James SP. (1986) The immunological basis of inflammatory bowel disease. J. Clin. Immunol. 6: 415-433.

2. Shanahan F, Targan S. (1989) In: Shaffer E, Thompson ABR, (ed). Modern Concepts in Gastroenterology. Plenum, New York, pp. 291310.

3. Strober W, Ehrhardt RO. (1993) Chronic intestinal inflammation: An unexpected outcome in cytokine or $\mathrm{T}$ cell receptor mutant mice. Cell 75: 203-205.

4. MacDonald TT, Spencer J. (1988) Evidence that activated mucosal $\mathrm{T}$ cells play a role in the pathogenesis of enterpathy in human small intestine. J. Exp. Med. 167: 1341-1349.

5. Mombaerts P, Mizoguchi E, Grusby MJ, et al. (1993) Spontaneous development of inflammatory bowel disease in $\mathrm{T}$ cell receptor mutant mice. Cell 75: 275-282.

6. Sadlack B, Merz H, Schorle H, et al. (1993) Ulcerative colitis-like disease in mice with a disrupted interleukin 2 gene. Cell 75: 253261.

7. Deusch K, Luling F, Reich K, et al. (1991) A major fraction of human intraepithelial lymphocytes simultaneously express the $\gamma \delta \mathrm{T}$ cell receptor, the CD8 accessory molecule and preferentially uses the $\mathrm{V} \delta 1$ gene segment. Eur. J. Immunol. 21: 1053-1059.

8. Boismenu R, Havran WL. (1994) Modulation of epithelial cell growth by intraepithelial $\gamma \delta$ T cells. Science 266: 1253-1255.

9. White B, Korn JH, Piela-Smith TH. (1994) Preferential adherence of human $\gamma \delta, \mathrm{CD}^{+}$ and memory $\mathrm{T}$ cells to fibroblasts. J. Immunol. 152: 4912-4918.

10. Galea P, Brezinschek R, Lipsky PE, Oppenheimer-Marks N. (1994) Phenotypic characterization of $\mathrm{CD}^{-} / \alpha \beta \mathrm{TCR}^{+}$and $\gamma \delta \mathrm{TCR}^{+} \mathrm{T}$ cells with a transendothelial migratory capacity. J. Immunol. 153: 529-542.

11. Kagnoff MF. (1996) Mucosal immunology: New frontiers. Immunol. Today 17: 57-59.

12. Halstensen TS, Scott H, Brandtzaeg P. (1989) Intraepithelial T cells of the TCR $\gamma \delta+\mathrm{CD} 8^{-}$ and $\mathrm{V} \delta 1 / \mathrm{J} \delta 1^{+}$phenotypes are increased in coeliac disease. Scand. J. Immunol. 30: 665672.

13. Spencer J, Isaacson PG, Diss TC, MacDonald TT. (1989) Expression of disulfide-linked and non-disulfide-linked forms of the $\mathrm{T}$ cell receptor $\gamma \delta$ heterodimer in human intestinal intraepithelial lymphocytes. Eur. J. Immunol. 19: 1335-1338.

14. Spencer J, Isaacson PG, MacDonald TT, Thomas AJ, Walker-Smith JA. (1991) Gam$\mathrm{ma} /$ delta $\mathrm{T}$ cells and the diagnosis of coeliac disease. Clin. Exp. Med. 85: 109-1 13.

15. Rust C, Pena S, Kluin P, Koning F. (1990) $\gamma \delta$ $\mathrm{T}$ cells in coeliac disease. Res. Immunol. 141: 668-671.

16. Trejdosiewicz LK, Calabrese A, Smart CJ, Oakes DJ, Howdle PD, Crabtree JE, Losowsky MS, Lancaster F, Boylston AW. (1991) $\gamma \delta \mathrm{T}$ cell receptor-positive cells of the human gastrointestinal mucosa: Occurrance and $\mathrm{V}$ region gene expression in Heliobacter pylori-associated gastrtis, coeliac disease and inflammatory bowel disease. Immunology 84: 440-444.

17. Fukashima K, Masuda T, Ohtani H, Sasaki I, Funayama Y, Matsuno S, Nagura H. (1991) Immunohistochemical characterization, distribution, and ultrastructure of lymphocytes bearing T-cell receptor $\gamma / \delta$ in inflammatory disease. Gastroenterology 101: 670-678. 
18. Stallmach A, Schuppan D, Riese HH, Matthes H, Riecken EO. (1992) Increased collagen type III synthesis by fibroblasts isolated from strictures of patients with Crohn's disease. Gastroenterology 102: 1920-1929.

19. Bull DM, Bookman MA. (1977) Isolation and functional characterization of human intestinal mucosal lymphoid cells. J. Clin. Invest. 59: 966-974.

20. Bookman MA, Bull DM. (1979) Characteristics of isolated intestinal mucosa lymphoid cells in inflammatory bowel disease. Gastroenterology 77: 513-520.

21. Selby WS, Janossy G, Bofill M, Jewell DP. (1984) Intestinal lymphocyte subpopulations in inflammatory bowel disease: An analysis by immunohistological and cell isolation techniques. Gut 25: 32-40.

22. Carding SR, Kyes $S$, Jenkinson EJ, Kingston $\mathrm{R}$, Bottomly K, Owen JJT, Hayday AC. (1990) Developmentally regulated fetal thymic and extrathymic T-cell receptor $\gamma \delta$ gene expression. Genes Dev. 4: 1304-1315.

23. Li B, Rossman MD, Imir T, Oner-Eyuboglu AF, Lee CW, Biancaniello R, Carding SR. (1996) Disease-specific changes in $\gamma \delta \mathrm{T}$ cell repertoire and function in patients with pulmonary tuberculosis. J. Immunol. 157: 42224229.

24. McVay LD, Carding SR. (1996) Extrathymic generation of $\gamma \delta \mathrm{T}$ cells bearing invariant antigen receptors during fetal development. J. Immunol. 157: 2873-2882.

25. McVay LD, Carding SR, Bottomly K, Hayday AC. (1991) Regulated expression and structure of TCR gamma delta transcripts in human thymic ontogeny. EMBO J. 10: 83-91.

26. Buschle $M$, Campana D, Carding SR, Richards C, Hoffbrand AV, Brenner MK. (1993) Interferon $\gamma$ inhibits apoptotic death in B cell chronic lymphocytic leukemia. J. Exp. Med. 177: 213-218.

27. Carding SR, McNamara JG, Pan M, Bottomly K. (1990) Characterization of $\gamma \delta \mathrm{T}$ cell clones isolated from human fetal liver and thymus. Eur. J. Immunol. 20: 1327-1335.

28. Borst J, van Dongen JJM, Bolhuis RLH, Peters PJ, Hafler DA, deVries E, van de Griend RJ. (1988) Distinct molecular forms of human T cell receptor $\gamma / \delta$ detected on viable $\mathrm{T}$ cells by a monoclonal antibody. J. Exp. Med. 167: 1625-1644.

29. Vroom T, Scholte G, Ossendorp F, Borst J. (1991) Tissue distribution of human $\gamma \delta \mathrm{T}$ cells: No evidence for general epithelial tropism. J. Clin. Pathol. 44: 1012-1017.

30. Porcelli S, Brenner MB, Band H. (1991) Biology of the human $\gamma \delta \mathrm{T}$-cell receptor. Immunol. Rev. 120: 137-183.

31. Fiocchi C. (1994) Cytokines. In: Targan SR, Shanahan $\mathrm{F}$ (eds). Inflammatory Bowel Disease, from Bench to Bedside. Williams and Wilkins, Baltimore, pp. 107-122.

32. Powrie $F$, Leach MW, Mauze S, Menon S, Caddle LB, Coffman RL. (1994) Inhibition of Thl responses prevents inflammatory bowel disease in scid mice reconstituted with CD45RBhi $\mathrm{CD}^{+} \mathrm{T}$ cells. Immunity 1: 553562.

33. Nakajima S, Roswit WT, Look DC, Holtzman MJ. (1995) A hierarchy for integrin expression and adhesiveness among $\mathrm{T}$ cell subsets that is linked to TCR gene usage and emphasizes $\mathrm{V} \delta 1^{+} \gamma \delta \mathrm{T}$ cell adherence and tissue retention. J. Immunol. 155: 1117-1131.

34. Groh V, Porcelli S, Fabbi M, Lanier LL, Picker $\mathrm{J}$, Anderson T, Warnke RA, Bhan AK, Strominger JL, Brenner M. (1989) Human lymphocytes bearing $\mathrm{T}$ cell receptor $\gamma / \delta$ are phenotypically diverse and evenly distributed throughout the lymphoid system. $J$. Exp. Med. 169: 1277-1294.

35. Chowers Y, Holtmeier W, Harwood J, Morzycka-Wroblewska E, Kagnoff MK. (1994) The $\mathrm{V} \delta 1$ receptor repertoire in human small intestine and colon. J. Exp. Med. 180: 183190.

36. Kersten CM, McCluskey RT, Boyle LA, Kurnick JT. (1996) Escherichia coli and Pseudomonas aeruginosa induce expansion of $V \delta 2$ cells in adult peripheral blood, but of $\mathrm{V} \delta 1$ cells in cord blood. J. Immunol. 157: 1613-1619.

37. Duchman R, Kaiser E, Hermann E, Mayet W, Ewe K, Meyer-Zum K-H. (1995) Tolerance exists towards resident intestinal flora but is broken in active inflammatory bowel disease. Clin. Exp. Immunol. 102: 448-455.

38. Janeway CA, Jr, Jones B, Hayday A. (1988) Specificity and function of T cells bearing $\gamma \delta$ T cell receptors. Immunol. Today 9: 73-77.

39. Munk ME, Schoel B, Modrow S, Karr RW, Young RA, Kaufmann SHE. (1989) T lymphocytes from healthy individuals with specificity to self-epitopes shared by mycobacterial and human 65-kilodalton heat shock protein. J. Immunol. 143: 2844-2849.

40. Haregewoin A, Soman G, Hom RC, Finberg RW. (1989) Human $\gamma \delta \mathrm{T}$ cells respond to 
mycobacterial heat-shock protein. Nature 340: 309-312.

41. Ebert EC. (1989) Proliferative responses of human intraepithelial lymphocytes to various T cell stimuli. Gastroenterology 978: 13721381 .

42. Pirzer UC, Schurmann G, Post S, Betzler M, Meuer S. (1990) Differential responsiveness to CD3Ti vs. CD2-dependent activation of human intestinal T lymphocytes. Eur. J. Immunol. 20: 2339-2342.

43. Qiao L, Schurmann G, Betzler M, Meuer S. (1991) Activation and signaling status of human lamina propria T lymphocytes. Gastroenterology 101: 1529-1536.

44. De Maria R, Fais S, Silvestri M, Frati L, Pallone F, Santoni A, Testi R. (1993) Continuous in vivo activation and transient hyporesponsiveness to TCR/CD3 triggering of human gut lamina propria lymphocytes. Eur. J. Immunol. 23: 3104-3108.

45. Targan SR, Deem RL, Liu M, Wang S, Nel A. (1995) Definition of a lamina propria $T$ cell responsive state: Enhanced cytokine responsiveness of $\mathrm{T}$ cells stimulated through the CD2 pathway. J. Immunol. 154: 664-675.

46. Fais S, Capobianchi MR, Pallone F, Di Marco P, Boirivant M, Dianzani F, Torsoli A. (1991) Spontaneous release of interferon- $\gamma$ by intestinal lamina propria lymphocytes in Crohn's disease. Kinetics of in vitro response to interferon $\gamma$ inducers. Gut 32: 103-107.

47. Mullin GE, Lazenby AJ, Harris ML, Bayless TM, James SP. (1992) Increased IL2-messenger RNA in the intestinal mucosal lesions of Crohn's disease but not ulcerative colitis. Gastroenterology 102: 1620-1627.

48. Brynskov J, Tvede N, Andersen CB, Vrlien $M$. (1992) Increased concentrations of interleukin $1 \beta$, interleukin 2 and soluble interleukin 2 receptors in endoscopical mucosal biopsy specimens with active inflammatory bowel disease. Gut 33: 55-58.

49. Fuss IJ, Neurath $M$, Boirivant $M$, Klein JS, de la Motte C, Strong SA, Fiocchi C, Strober W. (1996) Disparate $\mathrm{CD}^{+}$lamina propria (LP) lymphokine secretion profiles in inflammatory bowel disease: Crohn's disease LP cells manifest increased secretion of IFN- $\gamma$, whereas ulcerative colitis LP cells manifest increased secretion of IL-5. J. Immunol. 157: 1261-1270.

50. Bouillier S, Cochet M, Poccia F, Gougeon ML. (1995) CDR3-independent $\gamma \delta \mathrm{V} \delta 1^{+} \mathrm{T}$ cell ex- pansion in the peripheral blood of HIV-infected persons. J. Immunol. 154: 1418-1431.

51. Deem RL, Shanahan F, Targan SR. (1991) Triggered human mucosal $\mathrm{T}$ cells release tumor necrosis factor-alpha and interferongamma which kill human colonic epithelial cells. Clin. Exp. Med. 83: 79-84.

52. Graham MF, Diegelmana RF, Elson CO, Lindblad WJ, Gotschalk N, Gay R. (1988) Collagen content and types in the intestineal strictures of Crohn's Disease. Gastroenterology 94: 257-265.

53. Mathew RC, Weinstock RJ. (1994) Granuloma formation. In: Targan SR, Shanahan F (eds). Inflammatory Bowel Disease, from Bench to Bedside. Williams and Wilkins, Baltimore, pp. 151-170.

54. Haas W, Pereira P, Tonegawa S. (1993) $\gamma / \delta \mathrm{T}$ cells. Annu. Rev. Immunol. 11: 637-685.

55. Sartor, RB. (1994) Cytokines in intestinal inflammation: Pathophysiological and clinical considerations. Gastroenterology 106: 533549.

56. Doherty PC, Allan W, Eichelberger M, Carding SR. (1992) Roles of $\alpha \beta$ and $\gamma \delta \mathrm{T}$ cell subsets in viral immunity. Annu. Rev. Immunol. 10: 123-151.

57. Hiromatsu K, Yoshikai Y, Matsuzaki G, Ohga S, Muramori K, Matsumoto K, Bluestone JA, Nomoto K. (1992) A protective role of $\gamma / \delta \mathrm{T}$ cells in primary infection with Listeria monocytogenes in mice. J. Exp. Med. 175: 49-56.

58. Rosat JP, MacDonald HR, Louis JA. (1993) A role for $\gamma \delta+\mathrm{T}$ cells during experimental infection of mice with Leishmania major. J. Immunol. 150: 550-555.

59. Skeen MJ, Zeigler HK. (1993) Induction of murine peritoneal $\gamma \delta \mathrm{T}$ cells and their role in resistance to bacterial infection. J. Exp. Med. 178: 971-984.

60. Tsuji M, Mombaerts P, LeFrancois L, Nussenzweig RS, Zavala F, Tonegawa S. (1993) $\gamma \delta \mathrm{T}$ cells contribute to immunity against the liver stages of malaria in $\alpha \beta \mathrm{T}$ cell deficient mice. Proc. Natl. Acad. Sci. U.S.A. 91: 345-349.

61. Carding SR, Allan W, McMickle A, Doherty PC. (1993) Activation of cytokine genes in T cells during primary and secondary murine influenza pneumonia. J. Exp. Med. 177: 475482.

62. Scott S, Pandolfi F, Kurnick JT. (1990) Fibroblasts mediate $\mathrm{T}$ cell survival: A proposed mechanism for retention of primed T cells. $J$. Exp. Med. 172: 1873-1876.

63. Avdalovic M, Fong D, Formby B. (1993) Ad- 
hesion and costimulation of proliferative responses of human $\gamma \delta \mathrm{T}$ cells by interaction of VLA-4 and VLA-5 with fibronectin. Immunol. Lett. 35: 101-105.

64. Forrester JM, Newman LS, Wang Y, King TEJ, Kotzin BL. (1993) Clonal expansion of lung $\mathrm{V} \delta 1^{+} \mathrm{T}$ cells in pulmonary sarcoidosis. J. Clin. Invest. 91: 4291-4302.

65. Soderstrom K, Halapi E, Nilsson E, Gronberg A, van Embden J, Klareskog L, Kiessling R. (1990) Synovial cells responding to a $65-\mathrm{kD}$ mycobacterial heat shock protein have a high proportion of a TCR $\gamma \delta$ subtype uncommon in peripheral blood. Scand. J. Immunol. 32: $503-515$.

66. Smith MD, Broker B, Moretta L, Ciccone E, Grossi CE, Edwards JCW, Yuksel F, Colaco B, Worman C, MacKenzie L, Kinne R, Weseloh G, Gluckert K, Lydyard PM. (1990) $\mathrm{T} \gamma \delta$ cells and their subsets in blood and synovial tissue from rheumatoid arthritis patients. Scand. J. Immunol. 32: 585-593.
67. Sioud M, Kjeldsen-Kragh J, Quayle A, Kalvenes $C$, Waalen $K$, Forre $O$, Natvig JB. (1990) The $\mathrm{V} \delta$ gene usage by freshly isolated $\mathrm{T}$ lymphocytes from synovial fluids in rheumatoid synovitis: A preliminary report. Scand. J. Immunol. 31: 415-421.

68. Kjeldsen-Kragh J, Quayle A, Kalvenes C, Forre O, Sorskaar D, Vinje O, Thoen J, Natvig JB. (1990) T $\gamma \delta$ cells in juvenile rheumatoid arthritis and rheumatoid arthritis. Scand J. Immunol. 32: 651-659.

69. Bucht A, Soderstrom K, Hultman T, Uhlen M, Nilsson E, Kiessling R, Groenberg A. (1992) T cell receptor diversity and activation markers in the $\mathrm{V}$ delta $\mathrm{l}$ subset of rheumatoid synovial fluid and peripheral blood T lymphocytes. Eur. J. Immunol. 22: 567-574.

70. Spiro HM. (1993) Complications of colitis: Extracolonic complications. In: Spiro HM (ed). Clinical Gastroenterology. McGraw-Hill, New York, pp. 746-759.

Communicated by H. Wigzell. Accepted January 16, 1997. 